Important note: This is the author's post-print version of a research paper that was accepted for publication in the journal Ecosystem Services (Elsevier). Therefore, it underwent full peer review but has not been through the copyediting, typesetting, pagination and proofreading process, which may lead to differences between this version and the published version: Baró, F., Gómez-Baggethun, E., Haase, D., 2017. Ecosystem service bundles along the urban-rural gradient: Insights for landscape planning and management. Ecosyst. Serv. 24, 147-159. doi:10.1016/j.ecoser.2017.02.021

Title:

\title{
Ecosystem service bundles along the urban-rural gradient: Insights for landscape planning and management
}

\author{
ORIGINAL RESEARCH ARTICLE
}

(1)

\section{Authors and affiliations:}

Francesc Baró $^{\mathrm{a}, \mathrm{b}}$, Erik Gómez-Baggethun ${ }^{\mathrm{c}, \mathrm{d}}$, Dagmar Haase ${ }^{\mathrm{e}, \mathrm{f}}$

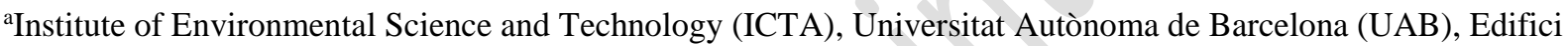
Z (ICTA-ICP), Carrer de les Columnes s/n, Campus de la UAB, 08193 Cerdanyola del Vallès, Spain

${ }^{\text {b} H o s p i t a l ~ d e l ~ M a r ~ M e d i c a l ~ R e s e a r c h ~ I n s t i t u t e ~(I M I M), ~ C a r r e r ~ D o c t o r ~ A i g u a d e r ~ 88, ~} 08003$ Barcelona, Spain cDepartment of International Environment and Development Studies (Noragric), Norwegian University of Life Sciences (NMBU), P.O. Box 5003, N-1432 Ås, Norway ${ }^{\mathrm{d} N o r w e g i a n}$ Institute for Nature Research (NINA), Gaustadalléen 21, 0349 Oslo, Norway e'Department of Geography, Lab for Landscape Ecology, Humboldt University of Berlin, Rudower Chaussee 16, 12489 Berlin, Germany

fDepartment of Computational Landscape Ecology, Helmholtz Centre for Environmental Research (UFZ), Permoser Straße 15, 04318 Leipzig, Germany

\section{Corresponding author:}

Francesc Baró

E-mail address: francesc.baro@uab.cat; Tel. (+34) 935868650 
Important note: This is the author's post-print version of a research paper that was accepted for publication in the journal Ecosystem Services (Elsevier). Therefore, it underwent full peer review but has not been through the copyediting, typesetting, pagination and proofreading process, which may lead to differences between this version and the published version: Baró, F., Gómez-Baggethun, E., Haase, D., 2017. Ecosystem service bundles along the urban-rural gradient: Insights for landscape planning and management. Ecosyst. Serv. 24, 147-159. doi:10.1016/j.ecoser.2017.02.021

\section{Abstract}

A key challenge of landscape planning and management is coping with multiple ecosystem service (ES) potentials and needs in complex social-ecological systems such as urban regions. However, few studies have analyzed both the supply and demand sides of ES bundles, i.e., sets of associated ES that repeatedly appear together across time or space, from an integrated perspective. This paper advances a framework to identify, map and assess ES bundles from a supply-demand approach to inform landscape planning and management. The framework is applied to the Barcelona metropolitan region, Spain, covering five ES and using eleven spatial indicators. Each indicator was quantified and mapped at the municipal level $(n=164)$ combining different proxy- and process-based models. Our results show significant associations among ES, both at the supply and demand sides. Further, we identified five distinct ES supply-demand bundle types and characterized them based on their specific ES relationships and their main underlying social-ecological conditions. From our findings, we call for combining land sharing strategies in urban and agricultural areas to increase landscape multifunctionality and, concurrently, assure the conservation of large periurban forest areas that are critical for delivering a wide range of local ES highly demanded by the urban population.

Keywords: Barcelona metropolitan region; ecosystem service mismatch; green infrastructure; spatial analysis; urban-rural gradient. 
Important note: This is the author's post-print version of a research paper that was accepted for publication in the journal Ecosystem Services (Elsevier). Therefore, it underwent full peer review but has not been through the copyediting, typesetting, pagination and proofreading process, which may lead to differences between this version and the published version: Baró, F., Gómez-Baggethun, E., Haase, D., 2017. Ecosystem service bundles along the urban-rural gradient: Insights for landscape planning and management. Ecosyst. Serv. 24, 147-159. doi:10.1016/j.ecoser.2017.02.021

\section{Introduction}

A key challenge of landscape planning and management is coping with multiple ecosystem service (ES) potentials and needs in complex social-ecological systems. The last decade has seen increasing attempts to assess the relationships among different ES through the concept of 'ES bundles' (e.g., Chan et al., 2006; Raudsepp-Hearne et al., 2010; Maes et al., 2012; Martín-López et al., 2012; García-Nieto et al., 2013; Renard et al, 2015). An ES bundle has been defined as "set of associated ES that repeatedly appear together across time or space" (Raudsepp-Hearne et al., 2010:5242; see also Box 1). A key advantage of the ES bundle approach is that it allows to assess potential synergies and trade-offs by analyzing how different ES in a given area are positively or negatively associated (Bennett et al., 2009; Box 1).

Assessment of ES bundles has been mostly applied to the supply side of ES (in terms of the ecosystem's potential to deliver ES or its actual flow sensu Villamagna et al., 2013; see Box 1) using a spatially explicit approach (e.g., Chan et al., 2006; Raudsepp-Hearne et al., 2010; Maes et al., 2012; Derkzen et al., 2015; Hamann et al., 2015; Queiroz et al., 2015) and, less frequently, also considering a temporal scale (e.g., Haase et al., 2012; Renard et al, 2015). In contrast, studies assessing ES bundles from a demand perspective (i.e., considering the amount of ES required or desired by society sensu Villamagna et al., 2013; see Box 1) have generally focused on determining different socio-cultural values (e.g., Martín-López et al., 2012; Iniesta-Arandia et al., 2014), but very few have produced spatially explicit information. The reason behind this disparity probably relates to the lack of a clear methodological framework for quantifying and mapping ES demand (Wolff et al., 2015) in contrast to ES supply (Egoh et al., 2012; Crossman et al., 2013; Malinga et al., 2015).

Even fewer studies have analyzed both the supply and demand sides of ES bundles from an integrated perspective (but see García-Nieto et al., 2013; Castro et al., 2014). Yet, such approach could have important advantages for sustainable landscape planning and management in complex social-ecological systems. These include: (1) enhanced capacity to address green infrastructure planning (GI), i.e., the identification of existing crucial ecosystems for ES delivery (Maes et al., 2015); (2) prioritization of key areas for establishing 
Important note: This is the author's post-print version of a research paper that was accepted for publication in the journal Ecosystem Services (Elsevier). Therefore, it underwent full peer review but has not been through the copyediting, typesetting, pagination and proofreading process, which may lead to differences between this version and the published version: Baró, F., Gómez-Baggethun, E., Haase, D., 2017. Ecosystem service bundles along the urban-rural gradient: Insights for landscape planning and management. Ecosyst. Serv. 24, 147-159. doi:10.1016/j.ecoser.2017.02.021

GI projects due to expected mismatches between supply and demand of ES from a bundle perspective (García-Nieto et al., 2013); and (3) better understanding of potential trade-offs and synergies between ES considering both ecosystem's processes and societal needs (Castro et al., 2014).

Considering both the supply and the demand sides of ES bundles can be particularly relevant in urban regions given their high levels of population density and pressure on available land. Assessing ES bundles in these areas can shed light on potential mismatches, trade-offs and synergies possibly driven by urban development processes. Even if urban areas benefit from the appropriation of vast ES providing areas beyond their boundaries (Rees, 1992; Folke et al., 1997), the local supply of ES can contribute to cope with a variety of 'demands', including protection from climate extremes (e.g., moderation of heatwaves and floods), improvement of environmental quality (e.g., air pollution abatement) and healthier life styles (e.g., opportunities for recreation and relaxation) (Bolund and Hunhammar, 1999; GómezBaggethun et al., 2013; Haase et al., 2014).

The aim of this paper is to advance a framework to identify, map and assess ES bundles from a supply-demand perspective in order to support landscape planning, management, and decision-making in urban regions. Our framework builds on previous methodological approaches (Mouchet et al., 2014) and consists of five main steps: (1) selection, quantification and mapping of suitable ES indicators (both at the supply and demand sides); (2) assessment of spatial ES associations at both sides; (3) identification of relevant ES supply-demand bundle types; (4) analysis of ES spatial patterns along the urban-rural gradient and along a gradient of management or planning strategies; and (5) understanding of the spatial characteristics of ES bundles and their relevance for landscape planning and management. We used the Barcelona metropolitan region, Spain, as case study area, considering a set of five ES and eleven indicators (six at the supply side and five at the demand side). 
Important note: This is the author's post-print version of a research paper that was accepted for publication in the journal Ecosystem Services (Elsevier). Therefore, it underwent full peer review but has not been through the copyediting, typesetting, pagination and proofreading process, which may lead to differences between this version and the published version: Baró, F., Gómez-Baggethun, E., Haase, D., 2017. Ecosystem service bundles along the urban-rural gradient: Insights for landscape planning and management. Ecosyst. Serv. 24, 147-159. doi:10.1016/j.ecoser.2017.02.021

Box 1. Definition of the main concepts discussed in this paper.

ES bundle is a set of associated ES that are supplied by or demanded from a given ecosystem or area and usually appear together repeatedly in time and/or space (modified from RaudseppHearne et al., 2010).

ES supply represents the capacity or potential of ecosystem's properties and functions to provide a specific bundle of ES within a given time period (modified from Villamagna et al., 2013). In this paper, we consider that ES supply, ES delivery and ES provision are synonymous terms, but these are different to ES flow, defined as the ES actually received, used or experienced by people (Villamagna et al., 2013).

ES demand is the amount of an ES required or desire by society (Villamagna et al., 2013). Therefore, the demand of a given ES may exceed its flow (and eventually its supply). Synergies and trade-offs are situations that arise when the use of one ES directly decreases (trade-off) or increases (synergy) the benefits provided by another. This may be due to simultaneous response to the same driver or due to true interactions among ES (Turkelboom et al., 2016).

ES mismatches are defined as the differences in quality or quantity occurring between the supply and demand of ES (Geijzendorffer et al., 2015).

Green infrastructure (GI) is a boundary concept with various conceptual meanings (Wright, 2011), but here we follow the EU GI strategy definition: "a strategically planned network of natural and semi-natural areas with other environmental features designed and managed to deliver a wide range of ES" (EC, 2013). 
Important note: This is the author's post-print version of a research paper that was accepted for publication in the journal Ecosystem Services (Elsevier). Therefore, it underwent full peer review but has not been through the copyediting, typesetting, pagination and proofreading process, which may lead to differences between this version and the published version: Baró, F., Gómez-Baggethun, E., Haase, D., 2017. Ecosystem service bundles along the urban-rural gradient: Insights for landscape planning and management. Ecosyst. Serv. 24, 147-159. doi:10.1016/j.ecoser.2017.02.021

\section{Material and methods}

\subsection{Case study area}

Our research was conducted in the Barcelona metropolitan region (BMR), north-east of Spain (Fig. 1A). The BMR $\left(3,244 \mathrm{~km}^{2}\right)$ is the most populous urban region on the Mediterranean coast with 5.03 million inhabitants (Statistical Institute of Catalonia, year 2015) distributed among 164 municipalities. Its urban core is constituted by the municipality of Barcelona (1.61 million inhabitants; $101 \mathrm{~km}^{2}$ ) and several adjacent middle-size cities characterized by very high population densities (Fig. 1B). The rest of the BMR is mostly structured in lower density towns, including several sprawling urban areas, except for seven dense sub-centers (municipalities between 50,000 and 200,000 inhabitants). Therefore, the BMR can be described as a polinuclear urban region, conceived as a hybrid between the compact and the dispersed urban models (Catalán et al., 2008).

Distribution of land uses and covers in the BMR is shaped by its physical geography. Two systems of mountain ranges (Catalan Coastal Range and Catalan Pre-Coastal Range) run parallel to the Mediterranean Sea coast, mostly covered by Mediterranean forests of Pine and Holm Oak trees, shrubland and grassland. Prominent examples of these ecosystems with high value for ES supply include protected areas such as the Montseny massif (Pre-Coastal Range) which has the highest peaks in the BMR (>1700 m), or the Collserola massif (Coastal Range) which is virtually enclosed by urban land (Fig. 1C). In contrast, coastal and inland plains are mostly covered by urban and agricultural land. For instance, the Llobregat river delta is heavily sealed by urban land and transport infrastructure (e.g., the Barcelona airport), but it still preserves valuable agricultural and wetland areas. The Penedès area (west of the BMR) is an important wine-growing region.

The BMR is one of the regional planning areas of the 'General Territorial Plan of Catalonia' (PTGC, 1995), the uppermost strategic landscape planning instrument in the region of Catalonia. The 'Territorial Metropolitan Plan of Barcelona' (PTMB) was developed following PTGC's guidelines and approved in 2010 by the Government of Catalonia (PTMB, 2010).

The PTMB establishes two main planning categories (called "systems") for land use regulation in the BMR: open areas and urban land (Fig. 1D). The open areas planning system 
Important note: This is the author's post-print version of a research paper that was accepted for publication in the journal Ecosystem Services (Elsevier). Therefore, it underwent full peer review but has not been through the copyediting, typesetting, pagination and proofreading process, which may lead to differences between this version and the published version: Baró, F., Gómez-Baggethun, E., Haase, D., 2017. Ecosystem service bundles along the urban-rural gradient: Insights for landscape planning and management. Ecosyst. Serv. 24, 147-159. doi:10.1016/j.ecoser.2017.02.021

$165\left(2405 \mathrm{~km}^{2}, 74.1 \%\right.$ of the BMR) regulates the land protected from urbanization and includes 166 three planning units: (1) Special protection areas $\left(2032 \mathrm{~km}^{2}\right)$, which consist of land that is 167 highly protected for its ecological and agricultural values, including Natura 2000 sites and 168 other protected areas; (2) Special protection of vineyards $\left(230 \mathrm{~km}^{2}\right)$, consisting of highly 169 protected land for its landscape and agricultural values for the wine sector; and (3) Preventive 170 protection areas $\left(143 \mathrm{~km}^{2}\right)$, for urban-rural transitional areas where urban development is 171 restricted, except in certain circumstances. The urban planning system $\left(840 \mathrm{~km}^{2}, 25.9 \%\right.$ of the 172 BMR) regulates consolidated built-up land $\left(635 \mathrm{~km}^{2}\right)$ and defines strategies for urban 173 expansion by the delimitation of development areas $\left(205 \mathrm{~km}^{2}\right)$ that can be subsequently 174 refined by municipalities through so-called local urban master plans.

176 We contend that the BMR, as a complex social-ecological system, is a suited testing area for 177 the purpose of this research. The manifest heterogeneous spatial distributions of relevant ES 178 providing areas (Mediterranean forests, agroecosystems, etc.) and potential beneficiaries 179 along the urban-rural gradient can provide relevant insights for the integration of a GI 180 perspective into future landscape planning and management instruments. 
Important note: This is the author's post-print version of a research paper that was accepted for publication in the journal Ecosystem Services (Elsevier). Therefore, it underwent full peer review but has not been through the copyediting, typesetting, pagination and proofreading process, which may lead to differences between this version and the published version: Baró, F., Gómez-Baggethun, E., Haase, D., 2017. Ecosystem service bundles along the urban-rural gradient: Insights for landscape planning and management. Ecosyst. Serv. 24, 147-159. doi:10.1016/j.ecoser.2017.02.021
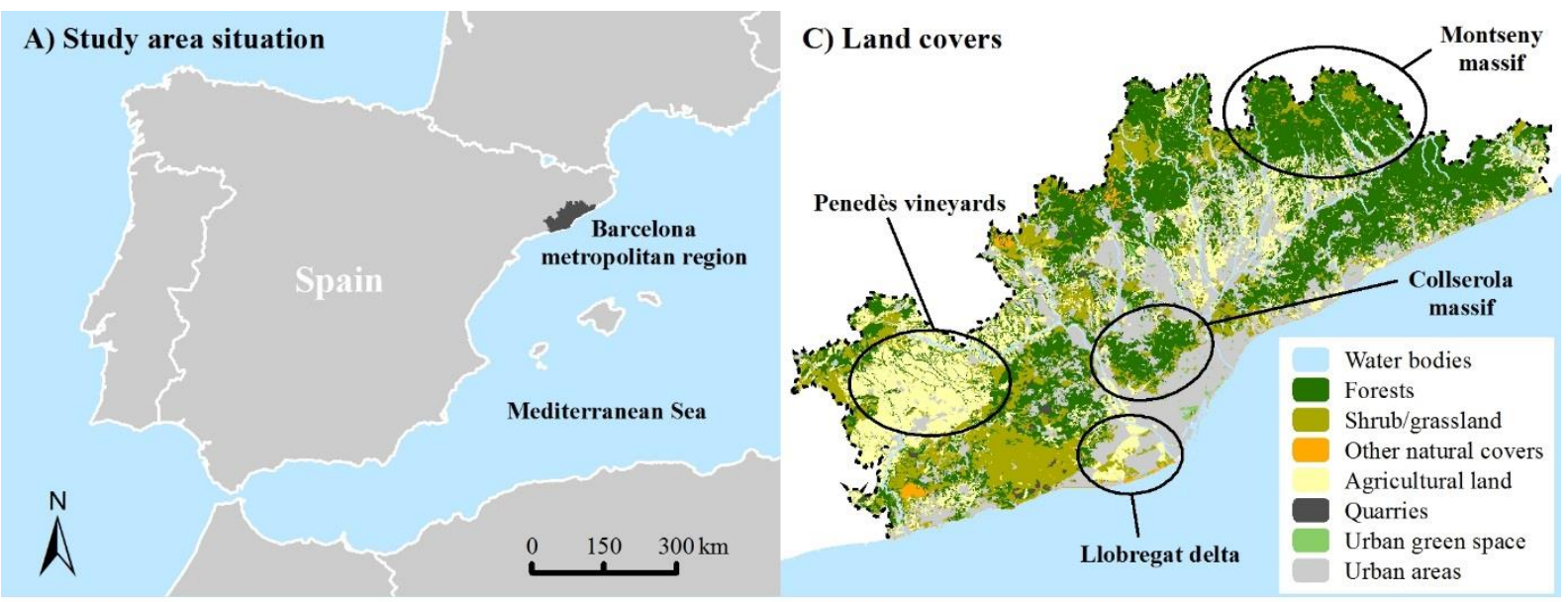

B) Demographics

D) Administrative and planning units
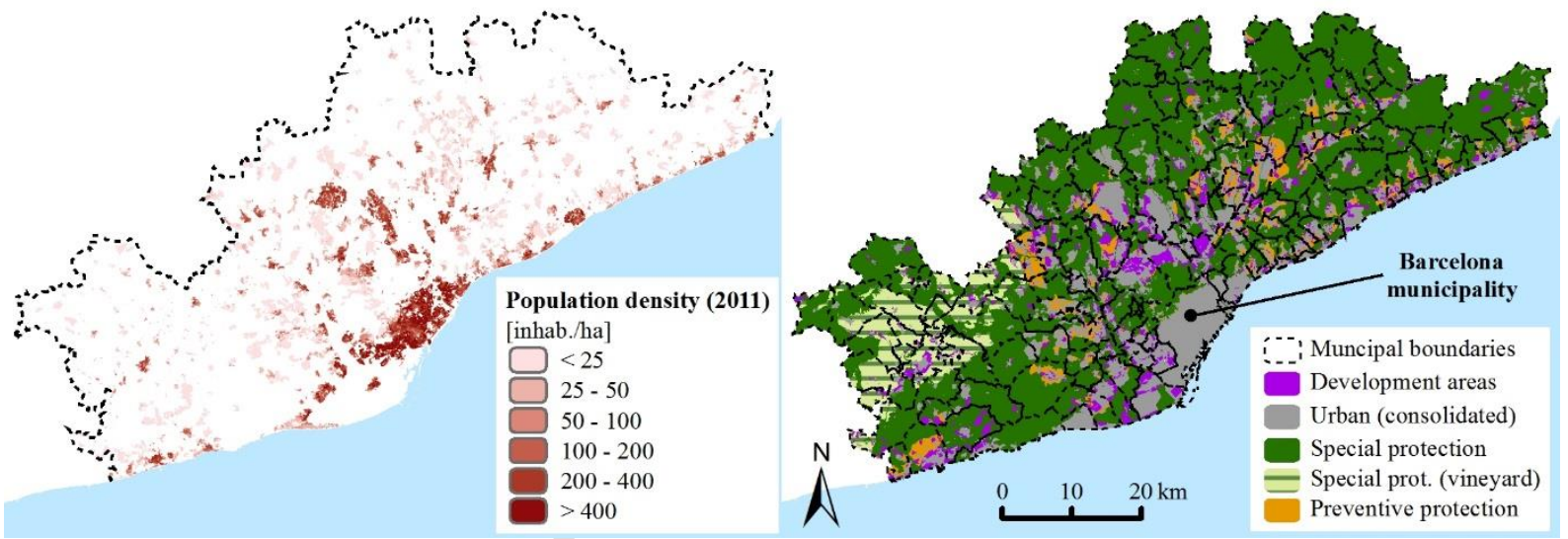

Fig. 1. Land cover, demographics and administrative maps of the case study area (Barcelona metropolitan region). Own elaboration based on various spatial datasets provided by the Catalan Government, the Catalan Cartographic and Geological Institute (ICGC) and the Spanish Statistical Office (INE).

\subsection{Selection, quantification and mapping of ecosystem service indicators}

Five ES were assessed at the study area: (1) food provision; (2) global climate regulation; (3) air purification; (4) erosion control; and (5) outdoor recreation (the terminology is based on the classification of urban ES by Gómez-Baggethun et al., 2013). The selection of these ES was based on three main criteria: (1) their relevance to the BMR, mainly in terms of expected demand; (2) consideration of a representative ES sample covering at least one ES from the three main ES categories of the $\mathrm{CICES}^{1}$ classification (i.e., provisioning, regulating and maintenance, cultural services); and (3) the availability of data for both ES supply and

\footnotetext{
${ }^{1}$ CICES (Common International Classification of Ecosystem Services) latest version is available from: http://cices.eu/
} 
Important note: This is the author's post-print version of a research paper that was accepted for publication in the journal Ecosystem Services (Elsevier). Therefore, it underwent full peer review but has not been through the copyediting, typesetting, pagination and proofreading process, which may lead to differences between this version and the published version: Baró, F., Gómez-Baggethun, E., Haase, D., 2017. Ecosystem service bundles along the urban-rural gradient: Insights for landscape planning and management. Ecosyst. Serv. 24, 147-159. doi:10.1016/j.ecoser.2017.02.021

demand sides. We consider that this selection satisfies the research goals and provides a sufficient ground for the discussion of possible relevant policy and planning implications.

For each ES, an indicator (based on direct or proxy data) was defined, measured and mapped, both at the supply and demand sides. In the case of food provision, two indicators of supply were used: crop and livestock production. Hence a total of eleven indicators were included in the analysis. Some indicators build on previous research studies in the case study area (e.g., Baró et al., 2016). Appendix A (Supplementary material) describes in detail the quantification and mapping methods (and provides the corresponding references) used for each ES indicator. Table 1 provides an overview of the ES indicators, key references, and a brief description of main data sources. Each indicator was quantified using the most recent available datasets (typically from years 2011 to 2013). All the required geoprocessing operations were carried out using ArcGIS v.10 (ESRI) or GRASS GIS v. 7.0 (GRASS Development Team).

As stated above, ES supply indicators refer here to the ecosystems' capacity to deliver ES, not the actual flow of ES (Villamagna et al., 2013; see also Box 1). The reason for using this approach is that we are interested in the long-term perspective and hence in measuring the potential of the study area in terms of ES provision regardless of whether this is actually used or experienced in the present. For example, the supply indicator for air purification $\left(\mathrm{NO}_{2}\right.$ dry deposition velocity) indicates the capacity of ecosystems to filter air pollution, but not the actual pollutant removal. In the case of provisioning indicators (both crop and livestock production), it could be assumed that most part of the production is consumed, yet food loss and food waste represents an important problem worldwide (FAO, 2011). Similarly, all carbon sequestration ecosystems' capacity constitutes a flow because global carbon emissions are clearly exceeding actual sequestration rates (Schröter et al., 2014). In the case of erosion control, a biophysical indicator could not be calculated due to data limitations, so we applied an ES expert-based matrix model using land covers as spatial data following Burkhard et al. (2012; 2014). The dimensionless index for outdoor recreation is based on a composite model (Paracchini et al., 2014; Zulian et al., 2014) that estimates the capacity of ecosystems to provide recreation opportunities based on their degree of naturalness, nature protection, and 
Important note: This is the author's post-print version of a research paper that was accepted for publication in the journal Ecosystem Services (Elsevier). Therefore, it underwent full peer review but has not been through the copyediting, typesetting, pagination and proofreading process, which may lead to differences between this version and the published version: Baró, F., Gómez-Baggethun, E., Haase, D., 2017. Ecosystem service bundles along the urban-rural gradient: Insights for landscape planning and management. Ecosyst. Serv. 24, 147-159. doi:10.1016/j.ecoser.2017.02.021

227 presence of water (see Baró et al., 2016 and Appendix A in Supplementary material for 228 further details).

230 Despite there is a varying understanding of the concept of ES demand (see Wolff et al., 2015),

231 ES demand refers here to "the amount or level of ES required or desired by society"

232 (Villamagna et al., 2013:116; see also Box 1). Following previous studies (e.g., Kroll et al., 233 2012), demand for food provision was mapped using human population density as proxy 234 indicator. We did not combine population density with average consumption rates because the focus of the research is not on self-sufficiency or balance analysis but on the assessment of the ES spatial patterns from a bundle approach. Demand indicators for regulating ES indicate the magnitude of pressures or inputs needing regulation (air pollution levels for air purification, carbon emissions for climate regulation and soil loss potential for erosion control). This risk reduction approach is commonly applied in the ES literature (Wolff et al., 2015) and assumes that demand is oriented toward a reduction of the indicator values (Burkhard et al., 2014). A particular case is again climate regulation because the demand for this ES is global and hence could be distributed equally over the world surface (Syrbe and Walz, 2012). Yet, carbon emissions are commonly used as a proxy at lower scales (e.g., Baró et al., 2015; Zhao and Sander, 2015) as a way to indicate local contributions to the need for this regulating ES. Finally, demand for experience-based cultural ES such as outdoor recreation can be estimated through the number of people wanting to experience the ES and their feasibility to do so in terms of accessibility to recreational sites (Paracchini et al., 2014; Ala-Hulkko et al., 2016). Following this rationale, here we mapped outdoor recreation demand based on the availability of recreational sites (i.e., areas identified as having a relevant recreation capacity) close to people's home and population density assuming that all inhabitants in the BMR have similar desires in terms of everyday life outdoor recreational opportunities (see Baró et al., 2016 and Appendix A in Supplementary material for details). 
Important note: This is the author's post-print version of a research paper that was accepted for publication in the journal Ecosystem Services (Elsevier). Therefore, it underwent full peer review but has not been through the copyediting, typesetting, pagination and proofreading process, which may lead to differences between this version and the published version: Baró, F., Gómez-Baggethun, E., Haase, D., 2017. Ecosystem service bundles along the urban-rural gradient: Insights for landscape planning and management. Ecosyst. Serv. 24, 147-159. doi:10.1016/j.ecoser.2017.02.021

Table 1. Overview of the ES indicators, quantification units, main data sources and key references used in the BMR case study. Full references for data sources are provided in Appendix A (Supplementary material).

\begin{tabular}{|c|c|c|c|}
\hline ES & Indicator / proxy & $\begin{array}{l}\text { Quantification } \\
\text { unit }\end{array}$ & Main data sources and key references \\
\hline \multirow{3}{*}{$\begin{array}{l}\text { Food } \\
\text { provision } \\
\text { (provisioning) }\end{array}$} & $\begin{array}{l}\text { Crop production } \\
\text { (supply) }\end{array}$ & $\begin{array}{l}\text { kg edible crop } \\
\text { production }^{-1} \\
\text { year }^{-1}\end{array}$ & $\begin{array}{l}\text { Agriculture yield statistical data (year 2013) } \\
\text { Kroll et al. (2012) }\end{array}$ \\
\hline & $\begin{array}{l}\text { Livestock } \\
\text { production } \\
\text { (supply) }\end{array}$ & $\begin{array}{l}\text { Livestock units } \\
\mathrm{km}^{-2} \text { year }^{-1}\end{array}$ & $\begin{array}{l}\text { Agriculture census data (year 2009) } \\
\text { Raudsepp-Hearne et al. (2010) }\end{array}$ \\
\hline & $\begin{array}{l}\text { Population } \\
\text { density (demand) }\end{array}$ & Inhabitants ha $^{-1}$ & $\begin{array}{l}\text { Population census tracts dataset (year 2011) } \\
\text { Burkhard et al. (2014) }\end{array}$ \\
\hline \multirow{2}{*}{$\begin{array}{l}\text { Global } \\
\text { climate } \\
\text { regulation } \\
\text { (regulating) }\end{array}$} & $\begin{array}{l}\text { Carbon } \\
\text { sequestration } \\
\text { (supply) }\end{array}$ & $\mathrm{kg} \mathrm{C} \mathrm{ha}^{-1}$ year $^{-1}$ & $\begin{array}{l}\text { National forest inventories data (years } 1990 \text { and 2001) } \\
\text { Pino (2007) }\end{array}$ \\
\hline & $\begin{array}{l}\text { Carbon emissions } \\
\text { (demand) }\end{array}$ & $\mathrm{kg} \mathrm{C} \mathrm{ha}^{-1}$ year $^{-1}$ & $\begin{array}{l}\text { Municipal Sustainable Energy Action Plans (SEAPs) } \\
\text { (year 2012) } \\
\text { Zhao and Sander (2015) }\end{array}$ \\
\hline \multirow{3}{*}{$\begin{array}{l}\text { Air } \\
\text { purification } \\
\text { (regulating) }\end{array}$} & \multirow{3}{*}{$\begin{array}{l}\mathrm{NO}_{2} \text { dry } \\
\text { deposition } \\
\text { velocity (supply) } \\
\mathrm{NO}_{2} \\
\text { concentration } \\
\text { levels (demand) }\end{array}$} & \multirow{3}{*}{$\begin{array}{l}\mathrm{mm} \mathrm{s}^{-1} \mathrm{ha}^{-1} \\
\mu \mathrm{g} \mathrm{NO}_{2} \mathrm{~m}^{-3} \\
\text { (annual mean) }\end{array}$} & $\begin{array}{l}\text { Regional land cover dataset (year 2012); Average wind } \\
\text { speed data (Regional environment database) }\end{array}$ \\
\hline & & & $\begin{array}{l}\text { Baró et al. (2016) } \\
\text { Air quality data from BMR monitoring stations (year } \\
\text { 2013) }\end{array}$ \\
\hline & & & Baró et al. (2016) \\
\hline \multirow{4}{*}{$\begin{array}{l}\text { Erosion } \\
\text { control } \\
\text { (regulating) }\end{array}$} & \multirow{2}{*}{$\begin{array}{l}\text { Erosion control } \\
\text { capacity (supply) }\end{array}$} & \multirow{2}{*}{$\begin{array}{l}\text { Dimensionless } \\
\text { index }(0-5)\end{array}$} & $\begin{array}{l}\text { Expert-based data and regional land covers dataset (year } \\
\text { 2012) }\end{array}$ \\
\hline & & & Burkhard et al. (2012) \\
\hline & \multirow[t]{2}{*}{$\begin{array}{l}\text { Soil loss potential } \\
\text { (demand) }\end{array}$} & \multirow[t]{2}{*}{$\begin{array}{l}\text { Dimensionless } \\
\text { index }(0-3)\end{array}$} & $\begin{array}{l}\text { Soil loss potential dataset (SITxell - Geographic } \\
\text { Information System for the Network of Open Areas in } \\
\text { the province of Barcelona) }\end{array}$ \\
\hline & & & Guerra et al. (2014) \\
\hline \multirow{3}{*}{$\begin{array}{l}\text { Outdoor } \\
\text { recreation } \\
\text { (cultural) }\end{array}$} & \multirow[t]{2}{*}{$\begin{array}{l}\text { Recreational } \\
\text { potential (supply) }\end{array}$} & \multirow[t]{2}{*}{$\begin{array}{l}\text { Dimensionless } \\
\text { index }(0-1)\end{array}$} & $\begin{array}{l}\text { Various regional spatial datasets on habitat naturalness, } \\
\text { protected natural areas and water features (various } \\
\text { sources) }\end{array}$ \\
\hline & & & Baró et al. (2016) \\
\hline & $\begin{array}{l}\text { Recreational } \\
\text { demand (demand) }\end{array}$ & $\begin{array}{l}\text { Dimensionless } \\
\text { index }(0-5)\end{array}$ & $\begin{array}{l}\text { Population census tracts dataset (year 2011) } \\
\text { Baró et al. (2016) }\end{array}$ \\
\hline
\end{tabular}


Important note: This is the author's post-print version of a research paper that was accepted for publication in the journal Ecosystem Services (Elsevier). Therefore, it underwent full peer review but has not been through the copyediting, typesetting, pagination and proofreading process, which may lead to differences between this version and the published version: Baró, F., Gómez-Baggethun, E., Haase, D., 2017. Ecosystem service bundles along the urban-rural gradient: Insights for landscape planning and management. Ecosyst. Serv. 24, 147-159. doi:10.1016/j.ecoser.2017.02.021

\subsection{Analysis of spatial patterns and associations between ecosystem services}

Individual ES indicators were mapped to visualize and compare their spatial patterns across the case study area. Although the spatial resolution of some data sources was relatively high (e.g., the regional land cover dataset was developed at a scale of 1:50,000), we used municipalities ( $n=164$ ) as the main spatial unit of analysis due to several reasons: (1) urban policies related to ES and GI in the BMR are usually implemented at the municipal level (e.g., Barcelona City Council, 2013); (2) the municipality is the smallest unit at which livestock census or carbon emissions data are available in the BMR; and (3) statistical computing limitations when dealing with data matrices derived from high resolution rasters. Therefore, ES indicators were quantified for each municipality calculating average values in case the original spatial unit was smaller and normalized by area to enable comparison across municipalities of different size. Further, ES indicators were standardized where necessary in a 0-1 range using minimum and maximum values, so that correlation or cluster analyses could be performed (Raudsepp-Hearne et al., 2010; Mouchet et al., 2014).

As a preliminary step, spatial autocorrelation analysis was carried out for each ES indicator using Global Moran's I with Rook contiguity in ArcGIS v 10 (ESRI). We considered the spatial pattern to be significantly clustered if the obtained z-score (standard deviation) was higher than 1.96 (95\% confidence level).

The analysis of ES associations and bundles types was carried out following Mouchet et al. (2014) and using R statistical software (R Core Team, 2015) and ArcGIS v10 (ESRI). First, associations between pairs of ES were detected using Pearson parametric correlation test both at the supply (fifteen pairs) and demand (ten pairs) sides.

Overlap analysis was also applied in order to spatially visualize the municipalities with the highest or lowest supply and demand aggregate values, as well as supply - demand spatial congruency. Aggregated ES supply and demand values were calculated using a simple unweighted summation of the standardized indicators' values at the municipality level. In addition, we mapped the "richness" in ES to indicate the spatial diversity of ES in the case study area. To do so, we accounted for the number of ES supplied and demanded in a 
Important note: This is the author's post-print version of a research paper that was accepted for publication in the journal Ecosystem Services (Elsevier). Therefore, it underwent full peer review but has not been through the copyediting, typesetting, pagination and proofreading process, which may lead to differences between this version and the published version: Baró, F., Gómez-Baggethun, E., Haase, D., 2017. Ecosystem service bundles along the urban-rural gradient: Insights for landscape planning and management. Ecosyst. Serv. 24, 147-159. doi:10.1016/j.ecoser.2017.02.021

291

substantial degree in each municipality. A substantial supply or demand was assumed if the indicator value was equal or higher than the average of the BMR.

In a second stage, we defined different ES supply-demand bundle types using cluster analysis. We classified municipalities into clusters based on similar combinations of both ES supply and demand values (i.e., ES supply-demand bundle types) using $K$-means clustering algorithm which minimizes within-group variability. The appropriate number of clusters was determined by analyzing the meaningfulness of different clustering outputs with the support of dendrograms and scree plots. The final ES supply-demand bundle types were visualized using star plots (showing average indicator values per cluster) and mapped using ArcGIS to show their spatial patterns in the BMR.

A principal component analysis (PCA) was also applied to analyze the relationships between the ES supply and demand indicators and the various land planning strategies (i.e., the planning classes defined in the PTMB). Land planning strategies were included in the PCA as the area percentage of each class per municipality.

Finally, the assessment of ES spatial patterns was complemented by analyzing the urban-rural gradients. Following previous contribution to this research area (Kroll et al., 2012; Larondelle and Haase, 2013), we computed urban-rural gradients of the ES supply and demand indicators considered in the analysis. A 50-km concentric buffer with 1-km intervals was created around the city center of Barcelona (Catalunya square), covering almost all the BMR area. For each concentric ring, the average ES value was calculated omitting null values. In order to improve visualization of the gradients, the analysis was not performed at the municipal level but at the pixel level (using the ES data resampled at a spatial resolution of 100m) and it was based on a reclassification of the ES values in five classes (0-4) using quintiles. 
Important note: This is the author's post-print version of a research paper that was accepted for publication in the journal Ecosystem Services (Elsevier). Therefore, it underwent full peer review but has not been through the copyediting, typesetting, pagination and proofreading process, which may lead to differences between this version and the published version: Baró, F., Gómez-Baggethun, E., Haase, D., 2017. Ecosystem service bundles along the urban-rural gradient: Insights for landscape planning and management. Ecosyst. Serv. 24, 147-159. doi:10.1016/j.ecoser.2017.02.021

\section{Results}

\subsection{Ecosystem service supply: spatial patterns and associations}

Spatial autocorrelation results show that all ES supply indicators were spatially clustered on the case study area. The obtained z-scores (Fig. 2) indicate that there is less than $1 \%$ likelihood that the individual spatial patterns could be the result of random chance. Geographic distributions of the six ES supply indicators (Fig. 2) revealed clear similarities and dissimilarities among them. On the one hand, potential supply of regulating ES and outdoor recreation was highest in the mountainous landscapes located at the north and northeast of the BMR, mostly covered by Mediterranean forests. On the other hand, the two food production indicators followed very distinct patterns. In the case of crop production, highest values were mostly found in the flat areas of the wine-making county of Penedès (at the west side of the BMR) and in other agricultural areas located along the coast (especially in the Llobregat river delta). Livestock production was mostly clumped in low-density population municipalities located at the hinterland plains, especially at the north and west of the BMR.

The correlation results between pairs of ES supply indicators are shown in Table 2. All pairs were significantly correlated, except those including livestock production. Associations among regulating ES and outdoor recreation were highly positively correlated (Pearson coefficient $>0.5$ ). Crop production was moderately negatively correlated with all regulating services (Pearson coefficient $<-0.3$ and $>-0.5$ ) and weakly negatively correlated with outdoor recreation (Pearson coefficient $>-0.3$ ).

Overlap analysis confirmed that the most relevant and multifunctional municipalities in terms of ES provision are located at the north and north-east of the BMR (Fig. 3), including the municipalities with a high share of forest habitats and containing small settlements. In contrast, highly urbanized municipalities (e.g., in the urban core) and those mostly covered by agricultural land showed the lowest aggregated values for ES supply and none or few ES provided in a relevant amount (value $\geq$ mean) (see Fig. 3). 
Important note: This is the author's post-print version of a research paper that was accepted for publication in the journal Ecosystem Services (Elsevier). Therefore, it underwent full peer review but has not been through the copyediting, typesetting, pagination and proofreading process, which may lead to differences between this version and the published version: Baró, F., Gómez-Baggethun, E., Haase, D., 2017. Ecosystem service bundles along the urban-rural gradient: Insights for landscape planning and management. Ecosyst. Serv. 24, 147-159. doi:10.1016/j.ecoser.2017.02.021
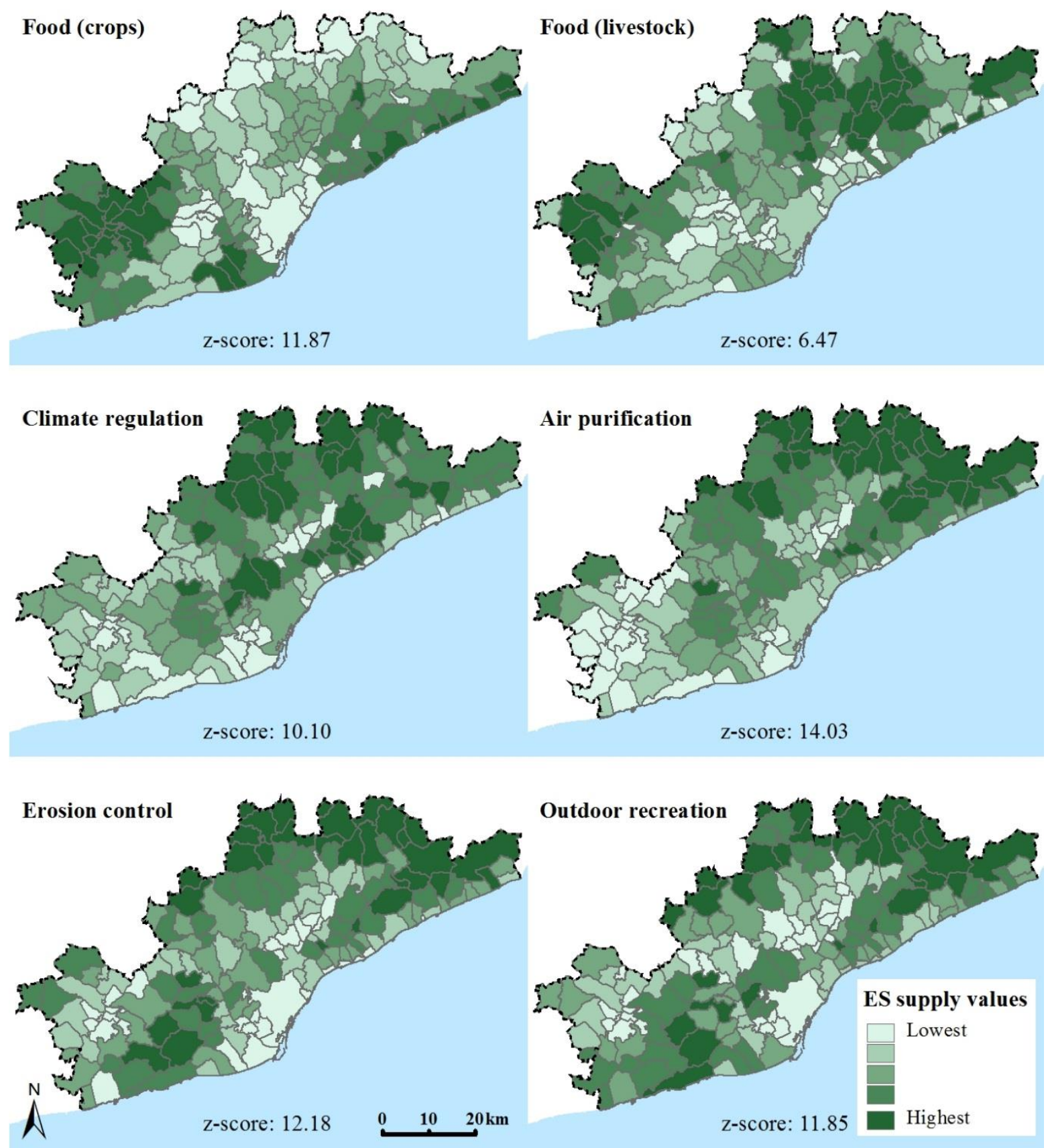

Fig. 2. Spatial patterns of the six ES supply indicators shown at the municipality level. Indicator values are classified in quintiles. All ES indicators are significantly clustered in space (z-score > 1.96). 
Important note: This is the author's post-print version of a research paper that was accepted for publication in the journal Ecosystem Services (Elsevier). Therefore, it underwent full peer review but has not been through the copyediting, typesetting, pagination and proofreading process, which may lead to differences between this version and the published version: Baró, F., Gómez-Baggethun, E., Haase, D., 2017. Ecosystem service bundles along the urban-rural gradient: Insights for landscape planning and management. Ecosyst. Serv. 24, 147-159. doi:10.1016/j.ecoser.2017.02.021

Table 2. Significant correlations (Pearson parametric test) between pairs of ES supply indicators $(* P<0.001 ; * * P$ $<0.0001)$

\begin{tabular}{lrrrrrr}
\hline & $\begin{array}{l}\text { Food } \\
\text { (crops) }\end{array}$ & $\begin{array}{l}\text { Food } \\
\text { (livestock) }\end{array}$ & $\begin{array}{l}\text { Climate } \\
\text { regulation }\end{array}$ & $\begin{array}{l}\text { Air } \\
\text { purification }\end{array}$ & $\begin{array}{l}\text { Erosion } \\
\text { control }\end{array}$ & $\begin{array}{l}\text { Outdoor } \\
\text { recreation }\end{array}$ \\
\hline Food (crops) & 1 & & & & & \\
Food (livestock) & 0.01 & 1 & & & & \\
Climate regulation & $-0.36^{* *}$ & 0.01 & 1 & & \\
Air purification & $-0.38^{* *}$ & 0.04 & $0.75^{* *}$ & 1 & 1 \\
Erosion control & $-0.41^{* *}$ & 0.01 & $0.68^{* *}$ & $0.86^{* *}$ & \\
Outdoor recreation & $-0.28^{*}$ & -0.09 & $0.65^{* *}$ & $0.79^{* *}$ & $0.86^{* *}$ & 1 \\
\hline
\end{tabular}

$\mathbf{N}^{\circ}$ of ES with relevant supply

(value $\geq$ mean)

- 1

- 2

- 3

○ 4

5-6
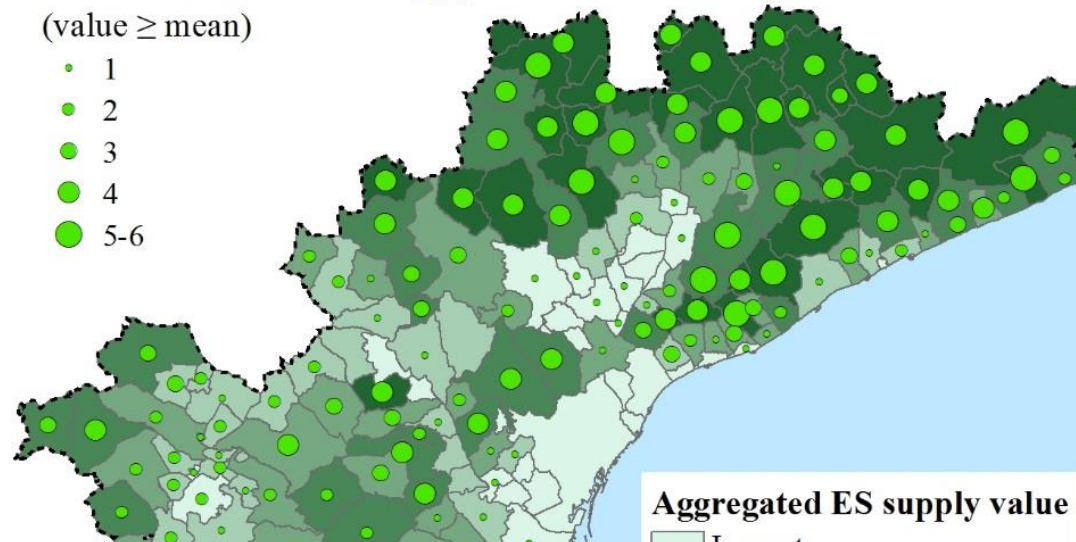

Aggregated ES supply value

$\mathrm{N}$
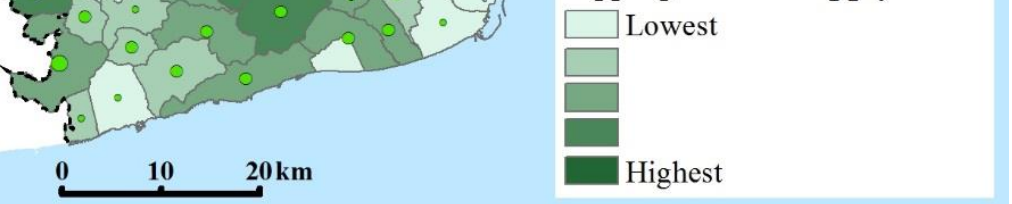

Fig. 3. Aggregated ES supply value and richness in ES, i.e., number of ES with relevant supply (value $\geq$ mean) shown at the municipality level. Aggregated ES supply values are classified in quintiles. 
Important note: This is the author's post-print version of a research paper that was accepted for publication in the journal Ecosystem Services (Elsevier). Therefore, it underwent full peer review but has not been through the copyediting, typesetting, pagination and proofreading process, which may lead to differences between this version and the published version: Baró, F., Gómez-Baggethun, E., Haase, D., 2017. Ecosystem service bundles along the urban-rural gradient: Insights for landscape planning and management. Ecosyst. Serv. 24, 147-159. doi:10.1016/j.ecoser.2017.02.021

361

362

363

364

365

366

367

368

369

370

371

372

373

374

375

376

377

378

379

380

381

382

383

384

385

\subsection{Ecosystem service demand: spatial patterns and associations}

All indicators of ES demand also showed a significant clustered spatial pattern on the BMR at the individual level (z-score > 1.96; Fig. 4). Furthermore, all indicators except erosion control displayed a similar spatial distribution characterized by highest values at the urban core (Barcelona and adjacent cities) and a clearly decreasing gradient towards the outskirts of the BMR (except for some municipalities, especially along the coastline). In contrast, demand for erosion control corresponded as expected mostly with the hilly areas located at the center and north-east of the BMR (Fig. 4).

All the ten possible pairwise associations between ES demand indicators were found to be significantly correlated (Table 3). Associations among food production, climate regulation, air purification and outdoor recreation were highly positively correlated (Pearson coefficient $>0.5$ ). Erosion control was moderately negatively correlated with food production, climate regulation and outdoor recreation (Pearson coefficient $<-0.3$ and $>-0.5$ ) and weakly negatively correlated with air purification (Pearson coefficient $>-0.3$ ).

As expected, overlap analysis showed that the aggregated ES demand values were highest in the urban core of the BMR (Fig. 5). Additionally, this area presented the highest diversity of demands: generally four or five ES were demanded in a relevant degree (indicator value $\geq$ mean). Lowest aggregated ES demand values were found mainly at the north and west of the BMR where municipalities are characterized by low population densities and a high share of agricultural or forest land covers. (1) 
Important note: This is the author's post-print version of a research paper that was accepted for publication in the journal Ecosystem Services (Elsevier). Therefore, it underwent full peer review but has not been through the copyediting, typesetting, pagination and proofreading process, which may lead to differences between this version and the published version: Baró, F., Gómez-Baggethun, E., Haase, D., 2017. Ecosystem service bundles along the urban-rural gradient: Insights for landscape planning and management. Ecosyst. Serv. 24, 147-159. doi:10.1016/j.ecoser.2017.02.021
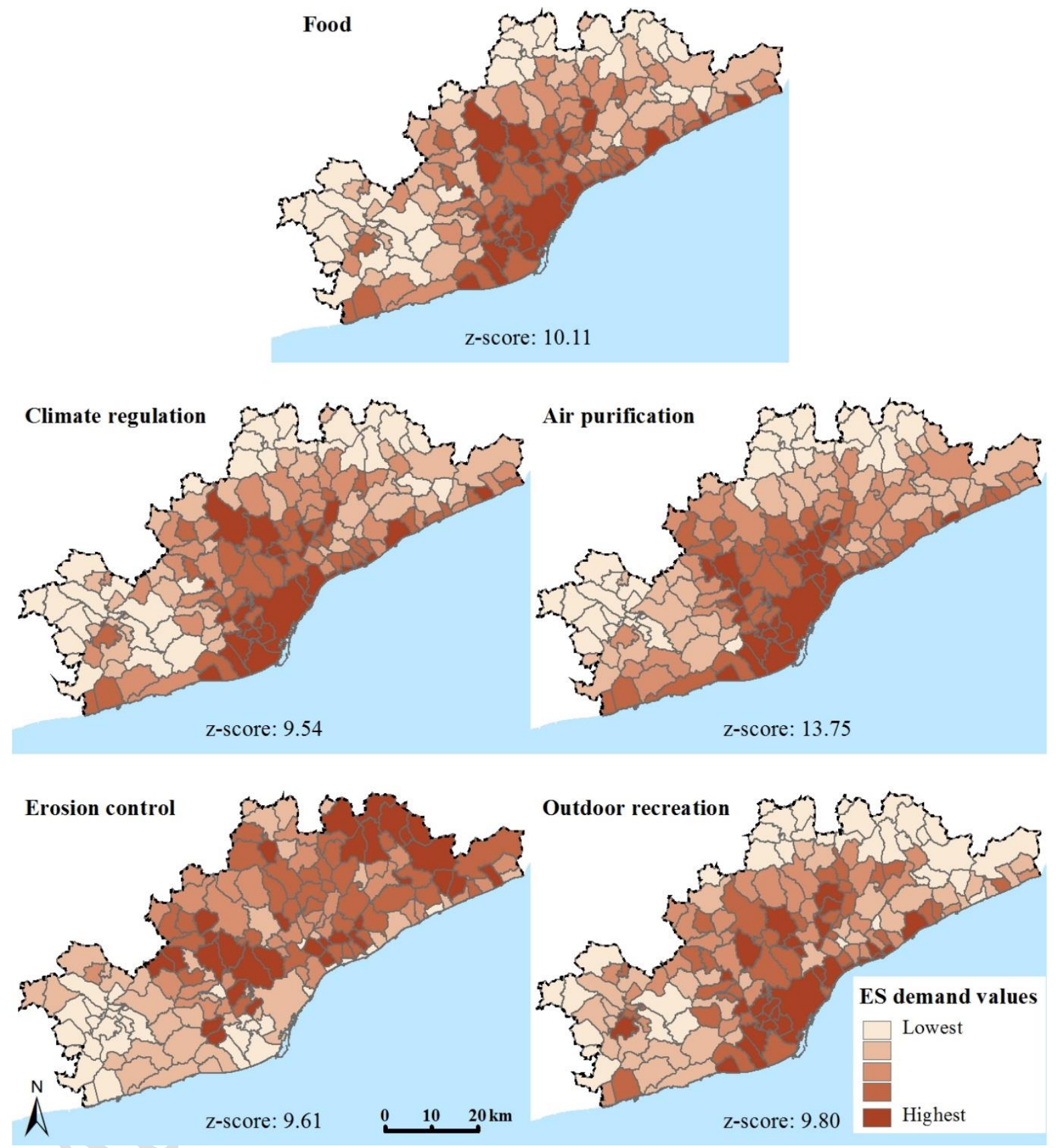

Fig. 4. Spatial patterns of the five ES demand indicators shown at the municipality level. Indicator values are classified in quintiles. All ES indicators are significantly clustered in space (z-score > 1.96). 
Important note: This is the author's post-print version of a research paper that was accepted for publication in the journal Ecosystem Services (Elsevier). Therefore, it underwent full peer review but has not been through the copyediting, typesetting, pagination and proofreading process, which may lead to differences between this version and the published version: Baró, F., Gómez-Baggethun, E., Haase, D., 2017. Ecosystem service bundles along the urban-rural gradient: Insights for landscape planning and management. Ecosyst. Serv. 24, 147-159. doi:10.1016/j.ecoser.2017.02.021

392 Table 3. Significant correlations (Pearson parametric test) between pairs of ES demand indicators $(* P<0.001$; $* * P<0.0001)$.

\begin{tabular}{|c|c|c|c|c|c|}
\hline & $\begin{array}{l}\text { Food } \\
\text { (population) }\end{array}$ & $\begin{array}{l}\text { Climate } \\
\text { regulation }\end{array}$ & $\begin{array}{l}\text { Air } \\
\text { purification }\end{array}$ & $\begin{array}{l}\text { Erosion } \\
\text { control }\end{array}$ & $\begin{array}{l}\text { Outdoor } \\
\text { recreation }\end{array}$ \\
\hline Food (population) & 1 & & & & \\
\hline Climate regulation & $0.92 * *$ & 1 & & & \\
\hline Air purification & $0.71 * *$ & $0.67 * *$ & 1 & & \\
\hline Erosion control & $-0.33 * *$ & $-0.37 * *$ & $-0.26^{*}$ & & \\
\hline Outdoor recreation & $0.90 * *$ & $0.86 * *$ & $0.67 * *$ & & \\
\hline
\end{tabular}

\section{$\mathrm{N}^{\circ}$ of ES with relevant demand}

(value $\geq$ mean)
- 1
- 2
- 3
4
5<smiles>[Te][Te]</smiles> 
Important note: This is the author's post-print version of a research paper that was accepted for publication in the journal Ecosystem Services (Elsevier). Therefore, it underwent full peer review but has not been through the copyediting, typesetting, pagination and proofreading process, which may lead to differences between this version and the published version: Baró, F., Gómez-Baggethun, E., Haase, D., 2017. Ecosystem service bundles along the urban-rural gradient: Insights for landscape planning and management. Ecosyst. Serv. 24, 147-159. doi:10.1016/j.ecoser.2017.02.021

\subsection{Ecosystem service bundles and urban-rural gradients}

Cluster analysis considering both the supply and demand indicators of ES allowed to group the 164 municipalities of the BMR into five clusters, hence revealing five distinct ES supplydemand bundle types (Table 4; Fig. 6). Spatial autocorrelation analysis determined that these five bundle types were also clustered on the BMR area (z-score $=2.28)$.

The five bundle types were named and characterized based on the specific supply-demand relationships and the main land uses taking place in each group. Cluster 1 was named "Urban core" because it comprises the municipality of Barcelona and several adjacent or nearby cities $(n=7)$. It is characterized by dense urbanization and very high population densities. This bundle type showed the lowest ES supply mean values and the highest ES demand values for all indicators except the demand for erosion control, revealing an overall ES mismatch from a bundle supply and demand perspective. Cluster $2(n=23)$, named "Suburban nodes", includes those municipalities with a very relevant amount of population and urbanized land, mostly located near the urban core or representing urban sub-centers in the BMR (Catalán et al., 2008). It displayed slightly higher ES supply mean values than the urban core and moderate ES demand values (from 0.21 to 0.27 ), except for air purification which was substantially higher (0.64). Cluster 3, named "Periurban green", is by far the largest bundle type by number of municipalities $(n=69)$. It comprises mostly municipalities with a relevant share of urban land, but also substantial amounts of forest and/or shrubland and, in some cases, also agricultural land. ES supply-demand relationships are characterized by low supply levels of food provision and climate regulation (yet higher than in the previous clusters), moderate to high supply values of air purification, erosion control and outdoor recreation (from 0.28 to 0.50), and a clear disparity of demands: food production, climate regulation and outdoor recreation are barely demanded while air purification and erosion control are demanded in moderate rates ( 0.36 and 0.44 respectively). Cluster $4(n=29)$, named "Cropland", groups those municipalities where land use is primarily agricultural (crops), basically located in the wine-making county of Penedès (west side of the BMR) and in other farming areas, mainly placed along the coast such as in the Llobregat River delta. All ES indicators, both at the supply and demand sides, showed low to moderate values (in the range $0.04-0.29$ ), except for crop production (0.53). Finally, Cluster $5(n=36)$ was called "Forestland" because it 
Important note: This is the author's post-print version of a research paper that was accepted for publication in the journal Ecosystem Services (Elsevier). Therefore, it underwent full peer review but has not been through the copyediting, typesetting, pagination and proofreading process, which may lead to differences between this version and the published version: Baró, F., Gómez-Baggethun, E., Haase, D., 2017. Ecosystem service bundles along the urban-rural gradient: Insights for landscape planning and management. Ecosyst. Serv. 24, 147-159. doi:10.1016/j.ecoser.2017.02.021

431 comprises inland municipalities mostly covered by woodland, where urban settlements are

432 generally small and agriculture is absent or minor. This ES bundle type showed by far the

433 highest supply values for regulating services and outdoor recreation and the lowest ES

434 demand values for all indicators except for erosion control which was highest (0.56).

435 Interestingly, this bundle mirrors the "urban core" cluster in the opposite direction regarding

436 the relationship between supply and demand, except for food supply values.

437 
Important note: This is the author's post-print version of a research paper that was accepted for publication in the journal Ecosystem Services (Elsevier). Therefore, it underwent full peer review but has not been through the copyediting, typesetting, pagination and proofreading process, which may lead to differences between this version and the published version: Baró, F., Gómez-Baggethun, E., Haase, D., 2017. Ecosystem service bundles along the urban-rural gradient: Insights for landscape planning and management. Ecosyst. Serv. 24, 147-159. doi:10.1016/j.ecoser.2017.02.021

Table 4. Standardized mean values for each ES indicator (both supply and demand) within each cluster or ES supply-demand bundle type. The number of municipalities per cluster is indicated with $n$.

\begin{tabular}{|c|c|c|c|c|c|c|}
\hline \multirow[b]{2}{*}{ ES } & & \multicolumn{5}{|l|}{ Clusters } \\
\hline & & $\begin{array}{l}\text { Urban core } \\
(n=7)\end{array}$ & $\begin{array}{l}\text { Suburban } \\
\text { nodes } \\
(n=23)\end{array}$ & $\begin{array}{l}\text { Periurban } \\
\text { green } \\
(n=69)\end{array}$ & $\begin{array}{l}\text { Cropland } \\
(n=29)\end{array}$ & $\begin{array}{l}\text { Forestland } \\
(n=36)\end{array}$ \\
\hline \multirow{3}{*}{ Food } & Supply (crops) & 0.04 & 0.06 & 0.09 & 0.53 & 0.05 \\
\hline & Supply (livestock) & 0.00 & 0.04 & 0.09 & 0.09 & 0.09 \\
\hline & Demand & 0.72 & 0.21 & 0.04 & 0.05 & 0.01 \\
\hline \multirow{2}{*}{$\begin{array}{l}\text { Climate } \\
\text { regulation }\end{array}$} & Supply & 0.03 & 0.05 & 0.18 & 0.04 & 0.43 \\
\hline & Demand & 0.77 & 0.27 & 0.06 & 0.10 & 0.02 \\
\hline \multirow{2}{*}{$\begin{array}{l}\text { Air } \\
\text { purification }\end{array}$} & Supply & 0.09 & 0.11 & 0.28 & 0.09 & 0.70 \\
\hline & Demand & 0.81 & 0.64 & 0.36 & 0.25 & 0.20 \\
\hline \multirow{2}{*}{$\begin{array}{l}\text { Erosion } \\
\text { control }\end{array}$} & Supply & 0.10 & 0.14 & 0.50 & 0.22 & 0.83 \\
\hline & Demand & 0.14 & 0.22 & 0.44 & 0.14 & 0.56 \\
\hline \multirow{2}{*}{$\begin{array}{l}\text { Outdoor } \\
\text { recreation }\end{array}$} & Supply & 0.14 & 0.25 & 0.40 & 0.29 & 0.66 \\
\hline & Demand & 0.76 & 0.25 & 0.10 & 0.11 & 0.02 \\
\hline
\end{tabular}

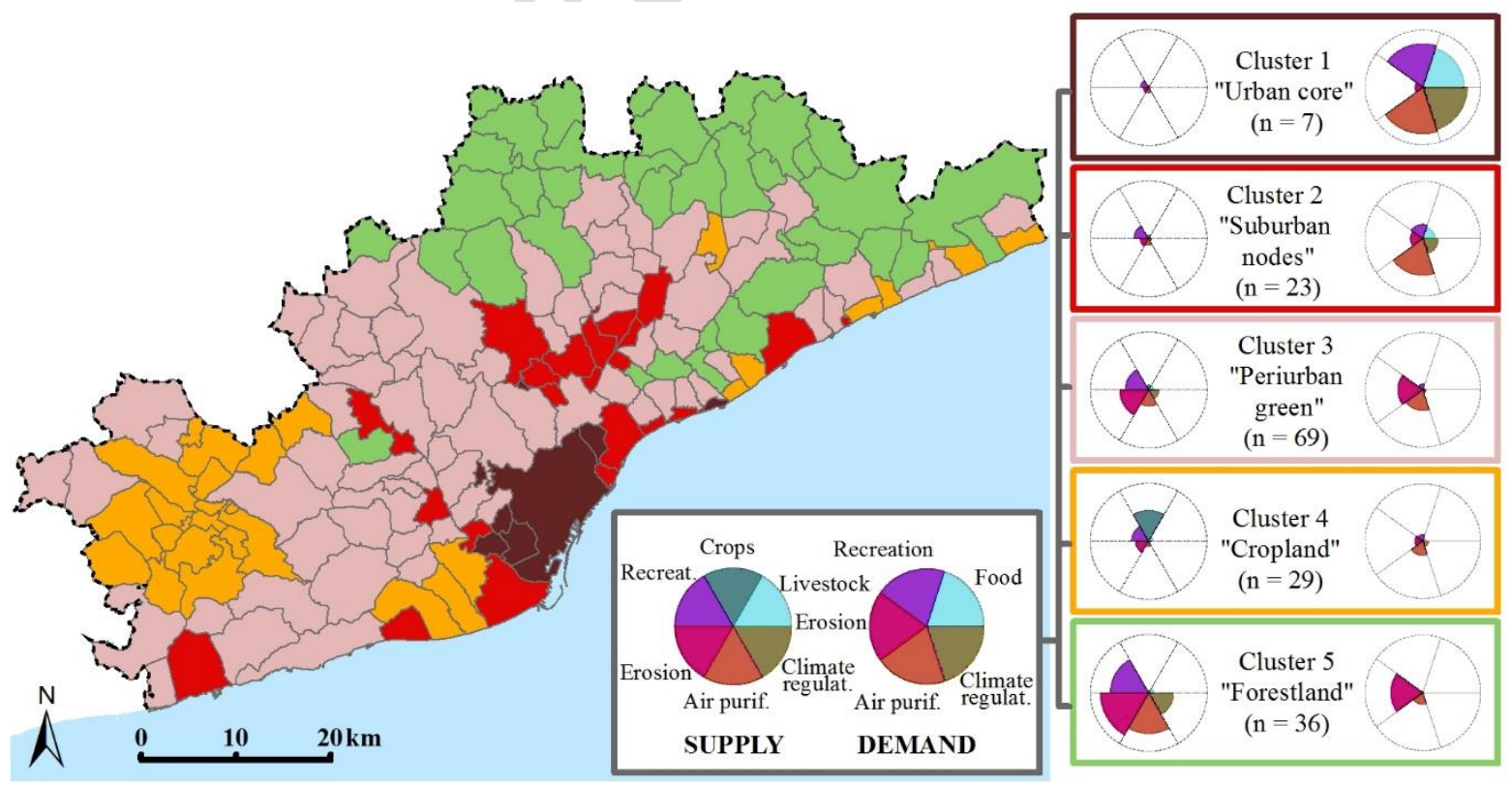

Fig. 6. Spatial distribution of ES supply-demand bundle types and standardized mean ES indicator values found within each cluster (represented in star plots). Outline colors of the cluster boxes link to the map classes, hence representing the map legend. The number of municipalities per cluster is indicated with $n$. 
Important note: This is the author's post-print version of a research paper that was accepted for publication in the journal Ecosystem Services (Elsevier). Therefore, it underwent full peer review but has not been through the copyediting, typesetting, pagination and proofreading process, which may lead to differences between this version and the published version: Baró, F., Gómez-Baggethun, E., Haase, D., 2017. Ecosystem service bundles along the urban-rural gradient: Insights for landscape planning and management. Ecosyst. Serv. 24, 147-159. doi:10.1016/j.ecoser.2017.02.021

447 PCA results revealed two main components explaining $70.79 \%$ of the total variance in the set

448 of eleven ES supply and demand indicators. The biplot of the PCA, representing these two

449 first axes, is shown in Fig. 7. The first axis of the PCA (50.65\% of the variance) showed a

450 potential trade-off between the supply of regulating services and outdoor recreation (highly

451 related to special protection planning strategy) and their demand (mostly related to urban

452 strategies), except in the case of the demand for erosion control which contributes positively

453 to PC1. The second axis of the PCA (20.14\% of the variance) revealed a potential trade-off

454 between the supply of food services (especially crop production) and all other ES indicators

455 (both at the supply and demand sides). As expected, special protection of the vineyard is

456 highly related to crop production due to the importance of the Penedès wine-making area.

Climate Food

regulation

Outdoor Air purification

recreation Urban

(consolidated)

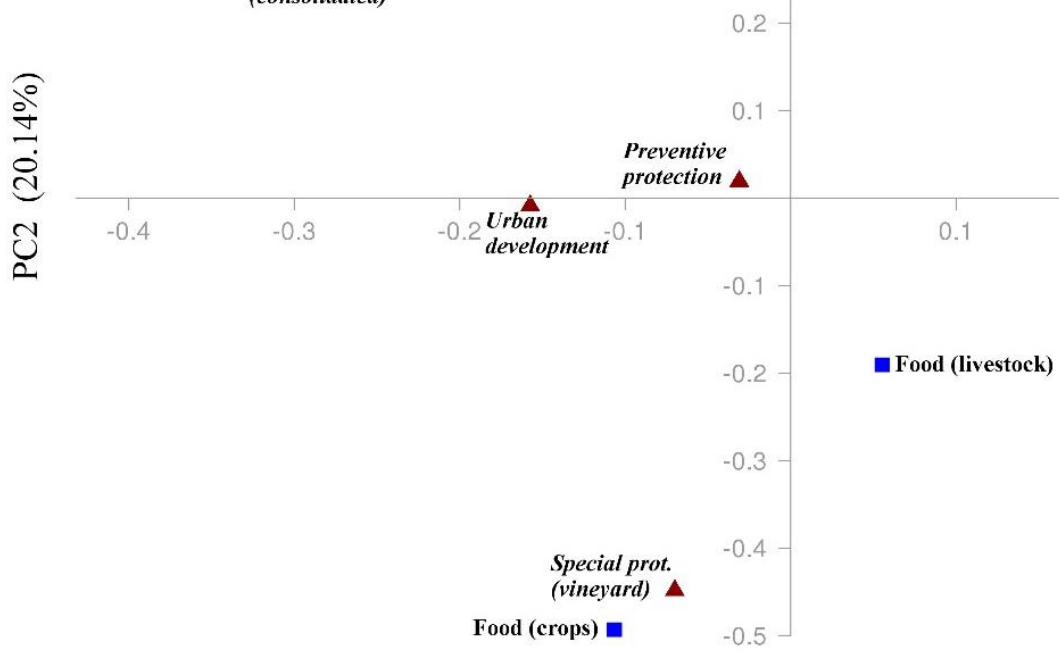

PC1 $(50.65 \%)$
Erosion

control Air purification

Climate

regulation Erosion

Outdoor a $\begin{aligned} & \text { Erosion } \\ & \text { control }\end{aligned}$

recreation

$\Delta$ Special

protection

Fig. 7. Biplot of the principal component analysis (PCA) for the ES supply and demand indicators and their relationship with land planning strategies (PTMB). 
Important note: This is the author's post-print version of a research paper that was accepted for publication in the journal Ecosystem Services (Elsevier). Therefore, it underwent full peer review but has not been through the copyediting, typesetting, pagination and proofreading process, which may lead to differences between this version and the published version: Baró, F., Gómez-Baggethun, E., Haase, D., 2017. Ecosystem service bundles along the urban-rural gradient: Insights for landscape planning and management. Ecosyst. Serv. 24, 147-159. doi:10.1016/j.ecoser.2017.02.021

463 The spatial urban-rural gradients of the ES indicators for the BMR illustrate graphically the 464 spatial patterns shown in the maps and described above. The gradients for ES supply showed 465 a similar mounting common trend in all indicators as distance to the urban core increases

466 (Fig. 8A). In all cases (except crop production), gradients revealed a substantial increase after $467 \mathrm{~km} \mathrm{5-6}$ followed by a slight decrease after $\mathrm{km} \mathrm{10-11} \mathrm{only} \mathrm{lasting} \mathrm{3-4} \mathrm{km} \mathrm{before} \mathrm{regaining} \mathrm{the}$ 468 growing trend. This pattern can be explained by the periurban areas surrounding the urban 469 core, mainly covered by forests (e.g., Collserola mountain range), shrubland or grassland, 470 which precede the urban and agricultural land located in the inland plains. Demand gradients 471 also showed a common similar pattern for all indicators, except erosion control (Fig. 8B).

472 Demand values for these indicators were highest in the urban core followed by a decreasing

473 trend as distance increases. Outdoor recreation and food production demand gradients

474 performed a sharp decline in the first $10 \mathrm{~km}$ whereas air purification and climate regulation

475 decreased more gradually because are less dependent to population density. Erosion control

476 demand gradient revealed a similar pattern as for supply, but following a steady trend after

$477 \mathrm{~km} 11$ rather than a growing one. 
Important note: This is the author's post-print version of a research paper that was accepted for publication in the journal Ecosystem Services (Elsevier). Therefore, it underwent full peer review but has not been through the copyediting, typesetting, pagination and proofreading process, which may lead to differences between this version and the published version: Baró, F., Gómez-Baggethun, E., Haase, D., 2017. Ecosystem service bundles along the urban-rural gradient: Insights for landscape planning and management. Ecosyst. Serv. 24, 147-159. doi:10.1016/j.ecoser.2017.02.021

\section{A) SUPPLY GRADIENTS}

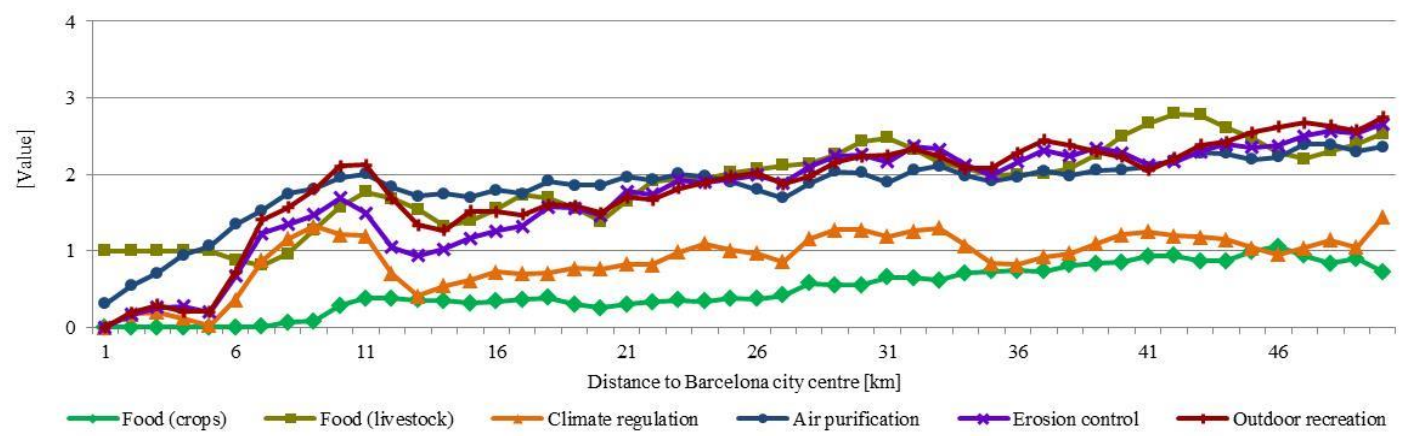

\section{B) DEMAND GRADIENTS}

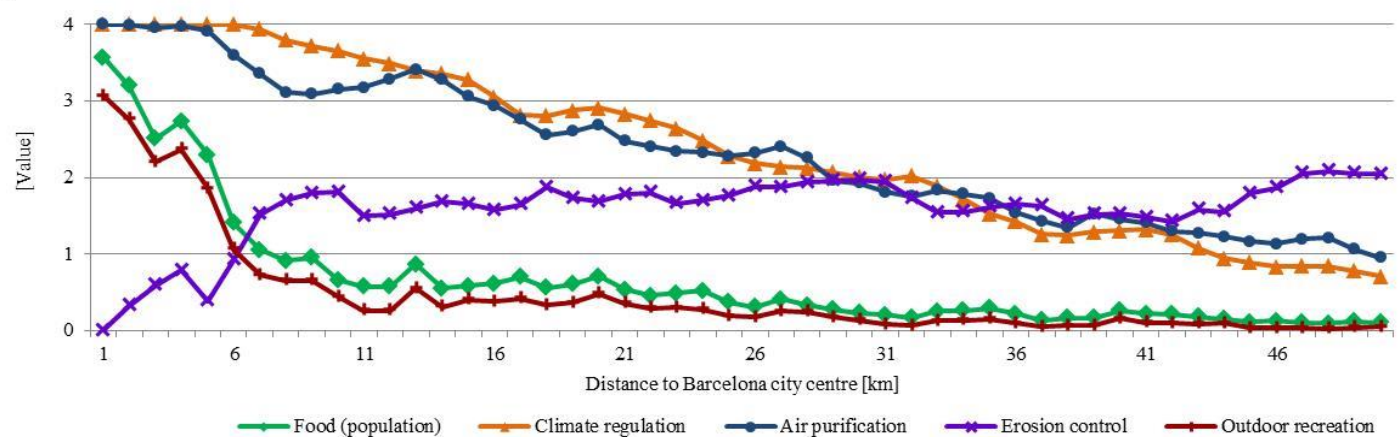

Fig. 8. Urban-rural gradients $(50 \mathrm{~km})$ of the ES supply and demand indicators for the BMR. Each point represents the average reclassified value (0-4 range) in the concentric ring at the respective distance from the Barcelona city center. Null values are not considered. 
Important note: This is the author's post-print version of a research paper that was accepted for publication in the journal Ecosystem Services (Elsevier). Therefore, it underwent full peer review but has not been through the copyediting, typesetting, pagination and proofreading process, which may lead to differences between this version and the published version: Baró, F., Gómez-Baggethun, E., Haase, D., 2017. Ecosystem service bundles along the urban-rural gradient: Insights for landscape planning and management. Ecosyst. Serv. 24, 147-159. doi:10.1016/j.ecoser.2017.02.021

\section{Discussion}

\subsection{Understanding ecosystem service bundles along the urban-rural gradient}

Our results show that land cover and the underlying social-ecological conditions decisively shape supply and demand patterns of ES in the BMR. Interestingly, the resulting ES supplydemand bundle types can be interpreted from a "land sharing" versus "land sparing" approach (Lin and Fuller, 2013). Municipalities under the "Urban core", "Cropland" and "Forestland" clusters follow largely a sparing landscape model based on one predominant land cover whereas the municipalities grouped into the "Suburban nodes" and "Periurban green" clusters could be classified as land sharing-based spatial configurations consisting of a mix of land covers.

These patterns are the result of complex historical processes. Mediterranean landscapes such as the BMR have been subject to increasing pressures over the last decades, leading to homogenization dynamics in terms of land use (Brandt and Vejre, 2003; Gómez-Baggethun et al. 2011). Since the 1950s, the BMR has experienced an accelerated urban development, driven by industrialization and associated migration from rural areas (within the BMR and beyond) to cities, especially to the urban core (Catalán et al., 2008). As a result, a gradual abandonment of traditional agrosilvopastoral practices took place, especially in mountainous areas, together with consequent forest densification and afforestation of open land (Otero et al., 2013). Only the most productive, easily-irrigable and accessible land parcels (mostly located in the lowlands) preserved their agricultural use (Marull et al., 2010).

Currently, "Cropland" municipalities are characterized by a landscape homogeneity which basically provides food products and are relatively poor in terms of capacity to deliver other ES. On the other hand, the landscape homogeneity of "Forestland" municipalities has a high potential to sequester carbon, remove air pollution, control erosion and provide recreation opportunities based on our analysis. Other assessments of ES supply bundles have showed similar results (e.g., Raudsepp-Hearne et al., 2010; Maes et al., 2012) indicating a clear positive association (i.e., synergy) between all the analyzed regulating ES and outdoor recreation and a significant negative association (i.e., trade-off) between crop production and these ES. At the same time, both "Cropland" and "Forestland" municipalities are sparsely 
Important note: This is the author's post-print version of a research paper that was accepted for publication in the journal Ecosystem Services (Elsevier). Therefore, it underwent full peer review but has not been through the copyediting, typesetting, pagination and proofreading process, which may lead to differences between this version and the published version: Baró, F., Gómez-Baggethun, E., Haase, D., 2017. Ecosystem service bundles along the urban-rural gradient: Insights for landscape planning and management. Ecosyst. Serv. 24, 147-159. doi:10.1016/j.ecoser.2017.02.021

517 urbanized and populated, which explains the low values they present for ES demand. An exception is erosion control demand, which (unlike the other ES) is not related to urban intensity factors but to geomorphologic aspects such as topographic slope. Consequently, "Forestland" municipalities, mostly located in hilly landscapes, have substantially higher demand values than "Cropland" municipalities which are basically situated in plains. As expected, our results also show that the widespread and dense urbanization characterizing "Urban core" municipalities reflect the highest potential mismatches between ES supply and demand when both are analyzed from a bundle perspective (again with the exception of erosion control). This is consistent with previous studies focused at the city level (Baró et al., 2014; 2015).

"Suburban nodes" and especially "Periurban green" municipalities are characterized by higher landscape heterogeneity and mix of land uses. As a result, ES bundles show a balanced situation between supply and demand mean normalized values, with some relevant exceptions such as air purification (especially in the "Suburban nodes" bundle), stressing the fact that air pollution problems are not only confined to highly urbanized land. However, it should be noted that a quantitative ES (mis)match or budget analysis as performed in other studies (e.g., Burkhard et al., 2012; 2014; Kroll et al., 2012) is not possible here because supply and demand indicators are not directly comparable. The only exception is climate regulation where both indicators have the same unit $\left(\mathrm{kg} \mathrm{C} \mathrm{ha}^{-1} \mathrm{year}^{-1}\right)$. Ratios showed that the carbon emissions considered are higher than carbon offsets provided by the local vegetation in all municipalities but five (all included in the "Forestland" cluster"). From the analysis of ES bundles, it is also worth pointing out that livestock production is not particularly prominent in any cluster. Unlike crop production, livestock farming does not necessarily require extensive land parcels (especially for pork or poultry); hence it probably holds a higher spatial compatibility with other land uses. However, results also indicate a likely trade-off with dense urbanization, probably because: (1) urban communities usually are unwilling to live close to industrial animal production sites (Raudsepp-Hearne et al., 2010); and (2) regional land use regulation directly establishes minimum distances between these farming sites and urban areas (which depend on the type of animal and other factors). 
Important note: This is the author's post-print version of a research paper that was accepted for publication in the journal Ecosystem Services (Elsevier). Therefore, it underwent full peer review but has not been through the copyediting, typesetting, pagination and proofreading process, which may lead to differences between this version and the published version: Baró, F., Gómez-Baggethun, E., Haase, D., 2017. Ecosystem service bundles along the urban-rural gradient: Insights for landscape planning and management. Ecosyst. Serv. 24, 147-159. doi:10.1016/j.ecoser.2017.02.021

\subsection{Insights for landscape planning and management}

The spatial relationship between ES supply and demand is a key issue for landscape planning and management (Syrbe and Walz, 2012). Previous studies (Costanza, 2008; Fisher et al., 2009; Burkhard et al., 2014) have classified ES according to their spatial characteristics suggesting several differentiated categories. Below, we analyze the spatial characteristics of the selected ES and discuss its implications for landscape planning and management in the BMR and similar urban regions in the light of the obtained results. Crop and livestock productions are classified as "decoupled" ES because, as most provisioning ES, they can be transported from the place of production to the place of consumption over long distances, involving in many cases complex supply chains (Burkhard et al., 2014). This characteristic allows metropolitan regions such as the BMR to let their food supply rely largely on food imports, at the same time that it allows that a substantial part of its food production is exported elsewhere (e.g., wine products from Penedès are exported worldwide). However, preserving farming areas in urban regions can also play an important role in terms of food security and resilience which should be considered in strategic landscape planning (Barthel and Isendahl, 2013; Camps-Calvet et al., 2016). Additionally, Mediterranean agricultural landscapes hold important cultural values such as aesthetic appreciation, sense of place and local ecological knowledge (Gómez-Baggethun et al., 2010), that are not included in this assessment. These aspects are often recognized in landscape planning and also reflected in consumer preferences for local food (Feldmann and Hamm, 2015). In the BMR, the Penedès vineyards and other agricultural areas are explicitly protected in regional planning instruments such as the PTMB (2010). Climate regulation was classified by Costanza (2008) as a "global non-proximal" ES because the benefits derived from carbon sequestration and storage by ecosystems are realized globally. Cities and urban regions, including the BMR, are generally far from having a net zero carbon footprint (see Escobedo et al., 2010; Liu and Li, 2012; Baró et al., 2015) and many of them have set substantial $\mathrm{CO}_{2}$ emissions reduction targets over the coming years (see for example the Covenant of Mayors initiative in Europe ${ }^{2}$ ). With regard to land use planning and decision-making, BMR's budget for climate regulation does not necessarily require achieving carbon neutrality, but regional and local policies could foster carbon reduction and offsetting actions both inside and beyond metropolitan boundaries (see

\footnotetext{
${ }^{2}$ See http://www.covenantofmayors.eu/index_en.html
} 
Important note: This is the author's post-print version of a research paper that was accepted for publication in the journal Ecosystem Services (Elsevier). Therefore, it underwent full peer review but has not been through the copyediting, typesetting, pagination and proofreading process, which may lead to differences between this version and the published version: Baró, F., Gómez-Baggethun, E., Haase, D., 2017. Ecosystem service bundles along the urban-rural gradient: Insights for landscape planning and management. Ecosyst. Serv. 24, 147-159. doi:10.1016/j.ecoser.2017.02.021

Seitzinger et al., 2012) so global climate regulation goals can be met in the long-term (currently municipal Sustainable Energy Action Plans define measures only at the local level). Air purification can be considered a "local proximal" or "omnidirectional" ES because benefits are realized in the ES providing area or its surrounding landscape without directional bias (Fisher et al., 2009). In terms of spatial planning, that means that urban green space and periurban green areas are key providing areas where the ES is actually delivered due to higher air pollution levels (Baró et al., 2016). Even if the reduction of air pollution emissions should be the first priority in urban policy, GI planning in the BMR can contribute to improve air quality if a land sharing approach is considered in urban development (Stott et al., 2015) and, concurrently, large periurban green areas such as the Collserola massif remain protected from urbanization (Depietri et al., 2016). The Barcelona Green Infrastructure and Biodiversity Plan 2020 (Barcelona City Council, 2013) is an interesting initiative towards a land sharing model in the urban core because it fosters the expansion of GI in all sorts of available land, including rooftops, inner courtyards, vacant plots, etc. Erosion control corresponds to an "in situ” ES because the benefit (soil retention) is realized in the same location of provision (Burkhard et al., 2014), but can also be considered "directional" (Costanza, 2008) because it can prevent erosion-related events such as landslides which benefit downhill areas. In this paper, we have basically analyzed the former condition due to indicator characteristics, showing an apparent synergetic relationship between supply and demand spatial patterns. This can be explained because the areas with higher risk of erosion due to geomorphologic factors (e.g., steepness in mountain ranges) are mostly covered by ecosystems with a high potential to control this process (e.g., forests) whereas land covers with low capacity (e.g., agro-ecosystems) are usually located in topographically less vulnerable areas. Regional urban planning regulation in the BMR currently favors this situation forbidding urban developments in areas where slope is higher than $20 \%$. Finally, outdoor recreation is classified as "in situ" or "user movement related" ES (Costanza, 2008) because, as most part of cultural ES, users need to actively reach providing areas in order to experience the related benefits. Therefore, accessibility is a key aspect for the assessment of outdoor recreation supply-demand relationships (Paracchini et al., 2014). Some studies have observed that beyond a threshold of 300-400 meter distance from home, the (everyday) recreational use of urban green space decreases substantially (Schipperijn et al., 2010). Furthermore, size of the providing area is also relevant because some outdoor activities (e.g., walking the dog, playing some sports, 
Important note: This is the author's post-print version of a research paper that was accepted for publication in the journal Ecosystem Services (Elsevier). Therefore, it underwent full peer review but has not been through the copyediting, typesetting, pagination and proofreading process, which may lead to differences between this version and the published version: Baró, F., Gómez-Baggethun, E., Haase, D., 2017. Ecosystem service bundles along the urban-rural gradient: Insights for landscape planning and management. Ecosyst. Serv. 24, 147-159. doi:10.1016/j.ecoser.2017.02.021

611

relaxation) can be realized in relatively small recreational patches (e.g., pocket parks), but others such as running or cycling require much larger areas. Therefore, in terms of spatial planning, this ES would require a combination of land sparing and land sharing models, as already considered by the English standard ANGSt (Accessible Natural Greenspace Standard, Natural England, 2010) or by other regional decision-support instruments (Van Herzele and Wiedemann, 2003). In the BMR, an effective harmonization of regional planning instruments such as the PTMB (2010) with municipal GI plans (e.g., Barcelona City Council, 2013) is required in order to achieve this arrangement of urban and periurban green spaces.

\subsection{Limitations and caveats}

The framework presented in this research could be potentially applied elsewhere since all data used is likely available in other urban regions. We consider that our assessment of ES bundles and its spatial outputs are sufficiently credible and salient for landscape and management purposes since all the indicators and proxies used here (both at the supply and demand sides) have been successfully applied in other policy-driven ES assessments (e.g., Burkhard et al., 2014; Guerra et al., 2014; Zhao and Sander, 2015; Baró et al., 2016; see also Table 1). Still, our methodological approach is challenged by a number of limitations and sources of uncertainty (see also Appendix A in Supplementary material).

One of the main limitations is that ES demand mapping relies on proxies (e.g., population density, air quality and distance to green areas) to indicate the expected amount of ES required by the urban population. Therefore, there is potential for error if the assumed causal variables are not in fact good spatial predictors (Eigenbrod et al., 2010). Validation or improvement of ES demand models could be achieved through complementary stakeholderbased approaches such as questionnaires, surveys or participatory mapping techniques (see Brown and Fagerholm, 2015). However, these methods are likely very cost and time intensive for urban regions such as the BMR due to its population size (Wolff et al., 2015).

A refinement of the ES indicators would also potentially allow to perform direct congruence analyses between supply and demand leading to additional policy and planning implications (Mouchet et al., 2014). Under its current approach, however, this research can be solely 
Important note: This is the author's post-print version of a research paper that was accepted for publication in the journal Ecosystem Services (Elsevier). Therefore, it underwent full peer review but has not been through the copyediting, typesetting, pagination and proofreading process, which may lead to differences between this version and the published version: Baró, F., Gómez-Baggethun, E., Haase, D., 2017. Ecosystem service bundles along the urban-rural gradient: Insights for landscape planning and management. Ecosyst. Serv. 24, 147-159. doi:10.1016/j.ecoser.2017.02.021

642

interpreted as the assessment of spatial patterns and associations between ES indicators from a supply- demand bundle perspective.

\section{Conclusions}

To our knowledge, this study presents the first assessment of ES bundles that integrates both the supply and demand sides in an urban-rural gradient. Our results show that urban and agricultural intensity is likely associated to lower potential and richness in terms of ES supply. Conversely, forest landscapes are characterized by a high multifunctionality, especially in regard to regulating ES, but most of these ES are barely demanded in these areas. Urbanization is also a clear driver at the demand side, as higher population densities and urban-related pressures (e.g., air pollution) inevitably entail increased needs for provisioning, regulating and cultural ES, generally leading to expected larger local mismatches between ES supply and demand. From an aggregated urban-rural gradient approach, the case study analyzed here shows inverse spatial patterns of ES supply and demand for all the considered ES, except for erosion control. This was already observed in other urban regions considering specific ES groups (e.g., Kroll et al., 2012), but not from a more holistic perspective.

With regard to landscape planning and management, a key aspect is taking into account the spatial scale relationships between ES supply and demand. The urban population needs nearby ecosystems in order to benefit from air purification or outdoor recreation services and, even if food or climate regulation can be provided from distant ecosystems, metropolitan regions such as the BMR have important motivations (e.g., food security, nature experience, climate adaptation and mitigation targets, etc.) to reduce their overall ES footprint. Based on these considerations, we argue that a promising approach could consist of combining land sharing strategies in urban and agricultural land in order to increase their multifunctionality and resilience (e.g., stricter GI ratios in urban development plans and fostering the provision of cultural ES in agricultural landscapes), and concurrently, assure the conservation of large patches of multifunctional periurban natural areas (such as the Collserola massif in the BMR). These periurban areas are vital for the fulfillment of certain ES bundle demands of the urban population, but they are generally more vulnerable to urbanization processes. 
Important note: This is the author's post-print version of a research paper that was accepted for publication in the journal Ecosystem Services (Elsevier). Therefore, it underwent full peer review but has not been through the copyediting, typesetting, pagination and proofreading process, which may lead to differences between this version and the published version: Baró, F., Gómez-Baggethun, E., Haase, D., 2017. Ecosystem service bundles along the urban-rural gradient: Insights for landscape planning and management. Ecosyst. Serv. 24, 147-159. doi:10.1016/j.ecoser.2017.02.021

\section{Acknowledgements}

674 We thank Arelly Ornelas (ICTA-UAB) and Carles Castell (Barcelona Regional Council) for

675 their support in this research. This research was partially funded by the 7th Framework

676 Program of the European Commission project 'OpenNESS' (code 308428), and by the

677 Barcelona Regional Council (Diputació de Barcelona) through an agreement of collaboration.

678 Francesc Baró also thanks the Fundación Iberdrola España for partial funding of this

679 research.

680 
Important note: This is the author's post-print version of a research paper that was accepted for publication in the journal Ecosystem Services (Elsevier). Therefore, it underwent full peer review but has not been through the copyediting, typesetting, pagination and proofreading process, which may lead to differences between this version and the published version: Baró, F., Gómez-Baggethun, E., Haase, D., 2017. Ecosystem service bundles along the urban-rural gradient: Insights for landscape planning and management. Ecosyst. Serv. 24, 147-159. doi:10.1016/j.ecoser.2017.02.021

\section{References}

Ala-Hulkko, T., Kotavaara, O., Alahuhta, J., Helle, P., Hjort, J., 2016. Introducing accessibility analysis in mapping cultural ecosystem services. Ecol. Indic. 66, 416-427. doi:http://dx.doi.org/10.1016/j.ecolind.2016.02.013

Barcelona City Council, 2013. Barcelona Green Infrastructure and Biodiversity Plan 2020. Retrieved from: http://www.bcn.cat/mediambient.

Baró, F., Chaparro, L., Gómez-Baggethun, E., Langemeyer, J., Nowak, D., Terradas, J., 2014. Contribution of Ecosystem Services to Air Quality and Climate Change Mitigation Policies: The Case of Urban Forests in Barcelona, Spain. Ambio 43, 466-479. doi:10.1007/s13280-014-0507-x

Baró, F., Haase, D., Gómez-Baggethun, E., Frantzeskaki, N., 2015. Mismatches between ecosystem services supply and demand in urban areas: A quantitative assessment in five European cities. Ecol. Indic. 55, 146158. doi:10.1016/j.ecolind.2015.03.013

Baró, F., Palomo, I., Zulian, G., Vizcaino, P., Haase, D., Gómez-Baggethun, E., 2016. Mapping ecosystem service capacity, flow and demand for landscape and urban planning: A case study in the Barcelona metropolitan region. Land use policy 57, 405-417. doi:10.1016/j.landusepol.2016.06.006

Barthel, S., Isendahl, C., 2013. Urban gardens, agriculture, and water management: Sources of resilience for long-term food security in cities. Ecol. Econ. 86, 224-234. doi:10.1016/j.ecolecon.2012.06.018

Bennett, E.M., Peterson, G.D., Gordon, L.J., 2009. Understanding relationships among multiple ecosystem services. Ecol. Lett. 12, 1394-404. doi:10.1111/j.1461-0248.2009.01387.x

Bolund, P., Hunhammar, S., 1999. Ecosystem services in urban areas. Ecol. Econ. 29, 293-301. doi:10.1016/S0921-8009(99)00013-0

Brandt, J., Vejre, H., 2003. Multifunctional Landscapes - motives, concepts and perspectives. In: Multifunctional Landscapes. Volume 1: Theory, Values and History. Brandt, J. and H. Vejre, (Eds.) 2003. pp. 3-31. WIT press, Southampton, UK.

Brown, G., Fagerholm, N., 2015. Empirical PPGIS/PGIS mapping of ecosystem services: A review and evaluation. Ecosyst. Serv. 13, 119-133. doi:10.1016/j.ecoser.2014.10.007

Burkhard, B., Kroll, F., Nedkov, S., Müller, F., 2012. Mapping ecosystem service supply, demand and budgets. Ecol. Indic. 21, 17-29. doi:http://dx.doi.org/10.1016/j.ecolind.2011.06.019

Burkhard, B., Kandziora, M., Hou, Y., Müller, F., 2014. Ecosystem Service Potentials, Flows and Demands Concepts for Spatial Localisation, Indication and Quantification. Landsc. Online 32, 1-32. doi:10.3097/LO.201434

Camps-Calvet, M., Langemeyer, J., Calvet-Mir, L., Gómez-Baggethun, E., 2016. Ecosystem services provided by urban gardens in Barcelona, Spain: Insights for policy and planning. Environ. Sci. Policy 62, 14-23. doi:10.1016/j.envsci.2016.01.007

Castro, A.J., Verburg, P.H., Martín-López, B., Garcia-Llorente, M., Cabello, J., Vaughn, C.C., López, E., 2014. Ecosystem service trade-offs from supply to social demand: A landscape-scale spatial analysis. Landsc. Urban Plan. 132, 102-110. doi:10.1016/j.landurbplan.2014.08.009

Catalán, B., Saurí, D., Serra, P., 2008. Urban sprawl in the Mediterranean? Landsc. Urban Plan. 85, $174-184$. doi:10.1016/j.landurbplan.2007.11.004

Chan, K.M.A., Shaw, M.R., Cameron, D.R., Underwood, E.C., Daily, G.C., 2006. Conservation Planning for Ecosystem Services. PLoS Biol. 4, e379. doi:10.1371/journal.pbio.0040379

Costanza, R., 2008. Ecosystem services: Multiple classification systems are needed. Biol. Conserv. 141, 350352.

Crossman, N.D., Burkhard, B., Nedkov, S., Willemen, L., Petz, K., Palomo, I., Drakou, E.G., Martín-Lopez, B., McPhearson, T., Boyanova, K., Alkemade, R., Egoh, B., Dunbar, M.B., Maes, J., 2013. A blueprint for mapping and modelling ecosystem services. Ecosyst. Serv. 4, 4-14. doi:http://dx.doi.org/10.1016/j.ecoser.2013.02.001

Depietri, Y., Kallis, G., Baró, F., Cattaneo, C., 2016. The urban political ecology of ecosystem services: The case of Barcelona. Ecol. Econ. 125, 83-100. doi:10.1016/j.ecolecon.2016.03.003 
Important note: This is the author's post-print version of a research paper that was accepted for publication in the journal Ecosystem Services (Elsevier). Therefore, it underwent full peer review but has not been through the copyediting, typesetting, pagination and proofreading process, which may lead to differences between this version and the published version: Baró, F., Gómez-Baggethun, E., Haase, D., 2017. Ecosystem service bundles along the urban-rural gradient: Insights for landscape planning and management. Ecosyst. Serv. 24, 147-159. doi:10.1016/j.ecoser.2017.02.021

Derkzen, M.L., van Teeffelen, A.J.A., Verburg, P.H., 2015. Quantifying urban ecosystem services based on high-resolution data of urban green space: an assessment for Rotterdam, the Netherlands. J. Appl. Ecol. 52, 1020-1032. doi:10.1111/1365-2664.12469

EC (European Commission), 2013. Green Infrastructure (GI) - Enhancing Europe's Natural Capital. Communication from the Commission to the European Parliament, the Council, the European Economic and Social Committee and the Committee of the Regions. COM (2013) 249 Final. Brussels. Retrieved from: http://eur-lex.europa.eu/legal-content/EN/TXT/?uri=CELEX\%3A52013DC0249

Egoh, B., Drakou, E.G., Dunbar, M.B., Maes, J., 2012. Indicators for mapping ecosystem services: a review. Publications Office of the European Union, Luxembourg. 111 pp. doi: 10.2788/41823

Eigenbrod, F., Armsworth, P.R., Anderson, B.J., Heinemeyer, A., Gillings, S., Roy, D.B., Thomas, C.D., Gaston, K.J., 2010. The impact of proxy-based methods on mapping the distribution of ecosystem services. J. Appl. Ecol. 47, 377-385. doi:10.1111/j.1365-2664.2010.01777.x

Escobedo, F.,J. Varela, S., Zhao, M., Wagner, J.E., Zipperer, W., 2010. Analyzing the efficacy of subtropical urban forests in offsetting carbon emissions from cities. Environ. Sci. Policy. 13, 362-372.

FAO (Food and Agriculture Organization), 2011. Global food losses and food waste - Extent, causes and prevention. Rome. Retrieved from: http://www.fao.org/docrep/014/mb060e/mb060e.pdf

Feldmann, C., Hamm, U., 2015. Consumers' perceptions and preferences for local food: A review. Food Qual. Prefer. 40, Part A, 152-164. doi:http://dx.doi.org/10.1016/j.foodqual.2014.09.014

Fisher, B., Turner, R.K., Morling, P., 2009. Defining and classifying ecosystem services for decision making. Ecol. Econ. 68, 643-653.

Folke, C., Jansson, A., Larsson, J., Costanza, R., 1997. Ecosystem appropriation by cities. Ambio 26, 167-172.

García-Nieto, A.P., García-Llorente, M., Iniesta-Arandia, I., Martín-López, B., 2013. Mapping forest ecosystem services: From providing units to beneficiaries. Ecosyst. Serv. 4, 126-138. doi:10.1016/j.ecoser.2013.03.003

Gómez-Baggethun, E., Mingorría, S., Reyes-García, V., Calvet, L., Montes, C., 2010. Traditional Ecological Knowledge Trends in the Transition to a Market Economy: Empirical Study in the Doñana Natural Areas. Conserv. Biol. 24, 721-729. doi:10.1111/j.1523-1739.2009.01401.x

Gómez-Baggethun, E., Martín-López, B., Lomas, P., Zorrilla, P., Montes, C. 2011. Evolution of ecosystem services in a Mediterranean cultural landscape: Doñana case study, Spain (1956-2006). In Sofo, A. (ed.), Biodiversity. InTech Press. pp. 27-46.

Gómez-Baggethun, E., Gren, Å., Barton, D., Langemeyer, J., McPhearson, T., O’Farrell, P., Andersson, E., Hamstead, Z., Kremer, P., 2013. Urban ecosystem services. In: Elmqvist, T., Fragkias, M., Goodness, J., Güneralp, B., Marcotullio, P., McDonald, R.I., Parnell, S., Schewenius, M., Sendstad, M., Seto, K.C., Wilkinson, C. (eds.), Urbanization, Biodiversity and Ecosystem Services: Challenges and Opportunities. Springer, pp. 175-251.

Guerra, C., Pinto-Correia, T., Metzger, M., 2014. Mapping Soil Erosion Prevention Using an Ecosystem Service Modeling Framework for Integrated Land Management and Policy. Ecosystems 17, 878-889. doi:10.1007/s10021-014-9766-4

Haase, D., Schwarz, N., Strohbach, M., Kroll, F., Seppelt, R., 2012. Synergies, Trade-offs, and Losses of Ecosystem Services in Urban Regions: an Integrated Multiscale Framework Applied to the Leipzig-Halle Region, Germany. Ecol. Soc. 17(3):22. doi:10.5751/ES-04853-170322

Haase, D., Larondelle, N., Andersson, E., Artmann, M., Borgström, S., Breuste, J., Gomez-Baggethun, E., Gren, Å., Hamstead, Z., Hansen, R., Kabisch, N., Kremer, P., Langemeyer, J., Rall, E., McPhearson, T., Pauleit, S., Qureshi, S., Schwarz, N., Voigt, A., Wurster, D., Elmqvist, T., 2014. A Quantitative Review of Urban Ecosystem Service Assessments: Concepts, Models, and Implementation. Ambio 43, 413-433. doi:10.1007/s13280-014-0504-0

Iniesta-Arandia, I., García-Llorente, M., Aguilera, P.A., Montes, C., Martín-López, B., 2014. Socio-cultural valuation of ecosystem services: uncovering the links between values, drivers of change, and human wellbeing. Ecol. Econ. 108, 36-48. doi:10.1016/j.ecolecon.2014.09.028

Kroll, F., Müller, F., Haase, D., Fohrer, N., 2012. Rural-urban gradient analysis of ecosystem services supply and demand dynamics. Land use policy 29, 521-535. doi:http://dx.doi.org/10.1016/j.landusepol.2011.07.008

Larondelle, N., Haase, D., 2013. Urban ecosystem services assessment along a rural-urban gradient: A crossanalysis of European cities. Ecol. Indic. 29, 179-190. doi:http://dx.doi.org/10.1016/j.ecolind.2012.12.022 
Important note: This is the author's post-print version of a research paper that was accepted for publication in the journal Ecosystem Services (Elsevier). Therefore, it underwent full peer review but has not been through the copyediting, typesetting, pagination and proofreading process, which may lead to differences between this version and the published version: Baró, F., Gómez-Baggethun, E., Haase, D., 2017. Ecosystem service bundles along the urban-rural gradient: Insights for landscape planning and management. Ecosyst. Serv. 24, 147-159. doi:10.1016/j.ecoser.2017.02.021

Lin, B.B., Fuller, R.A., 2013. FORUM: Sharing or sparing? How should we grow the world's cities? J. Appl. Ecol. 50, 1161-1168. doi:10.1111/1365-2664.12118

Liu, C., Li, X., 2012. Carbon storage and sequestration by urban forests in Shenyang, China. Urban For. Urban Green. 11, 121-128. doi:10.1016/j.ufug.2011.03.002

Maes, J., Paracchini, M.L., Zulian, G., Dunbar, M.B., Alkemade, R., 2012. Synergies and trade-offs between ecosystem service supply, biodiversity, and habitat conservation status in Europe. Biol. Conserv. 155, 1-12. doi:http://dx.doi.org/10.1016/j.biocon.2012.06.016

Maes, J., Barbosa, A., Baranzelli, C., Zulian, G., e Silva, F., Vandecasteele, I., Hiederer, R., Liquete, C., Paracchini, M.L., Mubareka, S., Jacobs-Crisioni, C., Castillo, C.P., Lavalle, C., 2015. More green infrastructure is required to maintain ecosystem services under current trends in land-use change in Europe. Landsc. Ecol. 30, 517-534. doi:10.1007/s10980-014-0083-2

Malinga, R., Gordon, L.J., Jewitt, G., Lindborg, R., 2015. Mapping ecosystem services across scales and continents - A review. Ecosyst. Serv. 13, 57-63. doi:http://dx.doi.org/10.1016/j.ecoser.2015.01.006

Martín-López, B., Iniesta-Arandia, I., García-Llorente, M., Palomo, I., Casado-Arzuaga, I., Amo, D.G. Del, Gómez-Baggethun, E., Oteros-Rozas, E., Palacios-Agundez, I., Willaarts, B., González, J.A., Santos-Martín, F., Onaindia, M., López-Santiago, C., Montes, C., 2012. Uncovering Ecosystem Service Bundles through Social Preferences. PLoS One 7, e38970.

Marull, J., Pino, J., Tello, E., Cordobilla, M.J., 2010. Social metabolism, landscape change and land-use planning in the Barcelona Metropolitan Region. Land use policy 27, 497-510. doi:http://dx.doi.org/10.1016/j.landusepol.2009.07.004

Mouchet, M.A., Lamarque, P., Martín-López, B., Crouzat, E., Gos, P., Byczek, C., Lavorel, S., 2014. An interdisciplinary methodological guide for quantifying associations between ecosystem services. Glob. Environ. Chang. 28, 298-308. doi:10.1016/j.gloenvcha.2014.07.012

Natural England, 2010. Nature Nearby’ Accessible Natural Greenspace Guidance. pp. 98. Retrieved from: http://publications.naturalengland.org.uk/publication/40004?category=47004

Otero, I., Boada, M., Tàbara, J.D., 2013. Social-ecological heritage and the conservation of Mediterranean landscapes under global change. A case study in Olzinelles (Catalonia). Land use policy 30, 25-37. doi:http://dx.doi.org/10.1016/j.landusepol.2012.02.005

Paracchini, M.L., Zulian, G., Kopperoinen, L., Maes, J., Schägner, J.P., Termansen, M., Zandersen, M., PerezSoba, M., Scholefield, P.A., Bidoglio, G., 2014. Mapping cultural ecosystem services: A framework to assess the potential for outdoor recreation across the EU. Ecol. Indic. 45, 371-385. doi:10.1016/j.ecolind.2014.04.018

Pino, J., 2007. Primera proposta de bases cartogràfiques, criteris i mètodes per a l'avaluació de l'estat ecològic del bosc a l'àmbit SITxell $i$ de les seves tendències a curt termini. Unpublished report for the Barcelona Regional Council.

PTGC (Territorial General Plan of Catalonia), 1995. Pla Territorial General de Catalunya. Retrieved from http://territori.gencat.cat/ca/01_departament/05_plans/ 01_planificacio_territorial/plans_territorials_nou/pla_territorial_general

PTMB (Territorial Metropolitan Plan of Barcelona), 2010. Pla Territorial Metropolità de Barcelona. Retrieved from http://territori.gencat.cat/ca/01_departament/05_plans/ 01_planificacio_territorial/plans_territorials_nou/territorials_parcials/ptp_metropolita_de_barcelona/

Queiroz, C., Meacham, M., Richter, K., Norström, A. V, Andersson, E., Norberg, J., Peterson, G., 2015. Mapping bundles of ecosystem services reveals distinct types of multifunctionality within a Swedish landscape. Ambio 44, 89-101. doi:10.1007/s13280-014-0601-0

R Core Team, 2015. R: A language and environment for statistical computing. R Foundation for Statistical Computing, Vienna, Austria. ISBN 3-900051-07-0, URL: http://www.R-project.org/.

Raudsepp-Hearne, C., Peterson, G.D., Bennett, E.M., 2010. Ecosystem service bundles for analyzing tradeoffs in diverse landscapes. Proc. Natl. Acad. Sci. 107 , 5242-5247. doi:10.1073/pnas.0907284107

Rees, W.E., 1992. Ecological footprints and appropriated carrying capacity: what urban economics leaves out. Environ. Urban. 4 , 121-130. doi:10.1177/095624789200400212

Renard, D., Rhemtulla, J.M., Bennett, E.M., 2015. Historical dynamics in ecosystem service bundles. Proc. Natl. Acad. Sci. 112, 13411-13416. doi:10.1073/pnas.1502565112 
Important note: This is the author's post-print version of a research paper that was accepted for publication in the journal Ecosystem Services (Elsevier). Therefore, it underwent full peer review but has not been through the copyediting, typesetting, pagination and proofreading process, which may lead to differences between this version and the published version: Baró, F., Gómez-Baggethun, E., Haase, D., 2017. Ecosystem service bundles along the urban-rural gradient: Insights for landscape planning and management. Ecosyst. Serv. 24, 147-159. doi:10.1016/j.ecoser.2017.02.021

Schipperijn, J., Ekholm, O., Stigsdotter, U.K., Toftager, M., Bentsen, P., Kamper-Jørgensen, F., Randrup, T.B., 2010. Factors influencing the use of green space: Results from a Danish national representative survey. Landsc. Urban Plan. 95, 130-137.

Schröter, M., Barton, D.N., Remme, R.P., Hein, L., 2014. Accounting for capacity and flow of ecosystem services: A conceptual model and a case study for Telemark, Norway. Ecol. Indic. 36, 539-551. doi:10.1016/j.ecolind.2013.09.018

Seitzinger, S., Svedin, U., Crumley, C., Steffen, W., Abdullah, S., Alfsen, C., Broadgate, W., Biermann, F., Bondre, N., Dearing, J., Deutsch, L., Dhakal, S., Elmqvist, T., Farahbakhshazad, N., Gaffney, O., Haberl, H., Lavorel, S., Mbow, C., McMichael, A., deMorais, J.F., Olsson, P., Pinho, P., Seto, K., Sinclair, P., Stafford Smith, M., Sugar, L., 2012. Planetary Stewardship in an Urbanizing World: Beyond City Limits. Ambio 41, 787-794. doi:10.1007/s13280-012-0353-7

Stott, I., Soga, M., Inger, R., Gaston, K.J., 2015. Land sparing is crucial for urban ecosystem services. Front. Ecol. Environ. 13, 387-393. doi:10.1890/140286

Syrbe, R.U., Walz, U., 2012. Spatial indicators for the assessment of ecosystem services: Providing, benefiting and connecting areas and landscape metrics. Ecol. Indic. 21, 80-88. doi:10.1016/j.ecolind.2012.02.013

Turkelboom F., Thoonen, M., Jacobs, S., García-Llorente, M., Martín-López, B., Berry, P. 2016. Ecosystem services trade-offs and synergies. In: Potschin, M. and K. Jax (eds): OpenNESS Ecosystem Services Reference Book. EC FP7 Grant Agreement no. 308428. Available via: www.opennessproject.eu/library/reference-book

Villamagna, A.M., Angermeier, P.L., Bennett, E.M., 2013. Capacity, pressure, demand, and flow: A conceptual framework for analyzing ecosystem service provision and delivery. Ecol. Complex. 15, 114-121. doi:10.1016/j.ecocom.2013.07.004

Van Herzele, A., Wiedemann, T., 2003. A monitoring tool for the provision of accessible and attractive urban green spaces. Landsc. Urban Plan. 63, 109-126. doi:10.1016/S0169-2046(02)00192-5

Wolff, S., Schulp, C.J.E., Verburg, P.H., 2015. Mapping ecosystem services demand: A review of current research and future perspectives. Ecol. Indic. 55, 159-171. doi:10.1016/j.ecolind.2015.03.016

Wright, H., 2011. Understanding green infrastructure: the development of a contested concept in England. Local Environ. 16, 1003-1019. doi:10.1080/13549839.2011.631993

Zhao, C., Sander, H.A., 2015. Quantifying and Mapping the Supply of and Demand for Carbon Storage and Sequestration Service from Urban Trees. PLoS One 10, e0136392.

Zulian, G., Polce, C., Maes, J., 2014. ESTIMAP: a GIS-based model to map ecosystem services in the European union. Ann. di Bot. 4, 1-7. doi:10.4462/annbotrm-11807 
Important note: This is the author's post-print version of a research paper that was accepted for publication in the journal Ecosystem Services (Elsevier). Therefore, it underwent full peer review but has not been through the copyediting, typesetting, pagination and proofreading process, which may lead to differences between this version and the published version: Baró, F., Gómez-Baggethun, E., Haase, D., 2017. Ecosystem service bundles along the urban-rural gradient: Insights for landscape planning and management. Ecosyst. Serv. 24, 147-159. doi:10.1016/j.ecoser.2017.02.021

\section{Appendix A. Supplementary material}

\section{Description of ecosystem service mapping methods and data sources}

\section{Food (crops)}

Crop production (supply indicator) in the BMR was estimated and mapped using two publicly available data sources: (1) 2013 agricultural yield statistical data (Catalan Ministry of Agriculture, 2013); and (2) a regional land cover dataset (Catalan Ministry of Territory and Sustainability, 2012). In order to clearly distinguish between crops for human food consumption and crops for other uses (fodder, materials, etc.), we received expert support from a regional farmers' union (Unió de Pagesos). Since the crop classes considered in the statistical data are more detailed than in the land cover map, we applied a table of correspondence between both categorizations following a previous study carried out by the farmer's union (Unió de Pagesos, 2013). For example, the statistical crop classes 'irrigated cereals', 'irrigated leguminous' and 'irrigated potatoes' were grouped into the agricultural land cover class 'irrigated herbaceous crops'. An average agricultural yield per agricultural land cover class (in $\mathrm{kg} \mathrm{ha}^{-1}$ year $^{-1}$ ) was estimated and mapped considering the different corresponding statistical crop yields weighted by their relative areas (Unió de Pagesos, 2013).

\section{Food (livestock)}

Livestock production (supply indicator) data were taken from the 2009 Spanish Agricultural Census (INE, 2009). Unlike crop production, the share of total livestock production directly allocated to human food consumption is very difficult to estimate; hence we used total livestock units (LSU) as a proxy indicator. Eurostat ${ }^{3}$ defines the livestock unit as "a reference unit which facilitates the aggregation of livestock from various species and age as per convention, via the use of specific coefficients established initially on the basis of the nutritional or feed requirement of each type of animal". The species considered in the case study area were bovine animals, sheep and goats, equidae, pigs, poultry and rabbits (breeding females). We mapped livestock units directly at the municipality level (normalized by area) because it is the smallest unit at which livestock census data were available. The number of

\footnotetext{
${ }^{3}$ See http://ec.europa.eu/eurostat/statistics-explained/index.php/Glossary:Livestock_unit_(LSU)
} 
Important note: This is the author's post-print version of a research paper that was accepted for publication in the journal Ecosystem Services (Elsevier). Therefore, it underwent full peer review but has not been through the copyediting, typesetting, pagination and proofreading process, which may lead to differences between this version and the published version: Baró, F., Gómez-Baggethun, E., Haase, D., 2017. Ecosystem service bundles along the urban-rural gradient: Insights for landscape planning and management. Ecosyst. Serv. 24, 147-159. doi:10.1016/j.ecoser.2017.02.021

897 livestock units produced per farm and its localization, as used in other studies (e.g., van Oudenhoven et al., 2012), were not available.

\section{Food (population density)}

901 Food provision demand was mapped using population density as a proxy indicator. A population density grid was generated based on an spatial intersect between a census tract dataset (INE, 2011) and residential land classes extracted from a high resolution land cover map (LCMC, 2009) assuming equal population distribution within residential land for each census tract.

\section{Global climate regulation}

908

909

910

The annual rate of carbon sequestration as supply indicator of global climate regulation was estimated based on above-ground tree biomass maps for the province of Barcelona from Pino (2007). The author used empirical data from two Spanish forest inventories (IFN2 and IFN3) and applied a land use regression (LUR) model considering various spatial predictors such as land cover, elevation and various climate variables. Carbon sequestration was estimated and mapped from tree biomass net growth between the two inventories considering a biomasscarbon ratio of 0.5 which approximates the proportional mass of carbon in the tree species of the case study (Gracia et al., 2000-2004).

Demand for climate regulation was based on annual carbon emissions estimated for each BMR municipality. Estimates were collected from municipal Sustainable Energy Action Plans (SEAPs) corresponding to the year 2012 by the Barcelona Regional Council ${ }^{4}$ accounting for emissions from sectors such as housing, transportation, services or waste management. Unfortunately, SEAPs' data did not include emissions from some relevant sectors such as industry or agriculture; therefore total values provide a first order estimate of the magnitude of carbon emissions at the municipal level.

\footnotetext{
${ }^{4}$ See http://www.diba.cat/en/web/mediambient/pactealcaldes
} 
Important note: This is the author's post-print version of a research paper that was accepted for publication in the journal Ecosystem Services (Elsevier). Therefore, it underwent full peer review but has not been through the copyediting, typesetting, pagination and proofreading process, which may lead to differences between this version and the published version: Baró, F., Gómez-Baggethun, E., Haase, D., 2017. Ecosystem service bundles along the urban-rural gradient: Insights for landscape planning and management. Ecosyst. Serv. 24, 147-159. doi:10.1016/j.ecoser.2017.02.021

926

927

928

929

930

931

932

933

934

935

936

937

938

939

940

941

942

943

944

945

946

947

948

949

950

951

952

953

954

955

956

\section{Air purification}

Methods and data sources for mapping the supply $\left(\mathrm{NO}_{2}\right.$ dry deposition velocity) and demand $\left(\mathrm{NO}_{2}\right.$ concentration levels) indicators of air purification in the BMR are fully described in Baró et al. (2016), hence here only a brief overview is provided. The supply indicator was estimated following the approach proposed by Pistocchi et al. (2010), which estimates deposition velocity (Vd) as a linear function of wind speed at $10 \mathrm{~m}$ height (w) and land cover type.

$\mathrm{V}_{\mathrm{d}}=\alpha_{\mathrm{j}}+\beta_{\mathrm{j}} \cdot \mathrm{w}$

Where $\alpha$ and $\beta$ are, respectively, the intercept and slope coefficients corresponding to each broad land cover type $j$, namely forest, bare soil, water or any combination thereof.

Concentration of $\mathrm{NO}_{2}$ (demand) was estimated using a LUR model, a computation approach widely used for assessing air pollution at different scales (e.g., Beelen et al. 2013). The LUR model was built using $\mathrm{NO}_{2}$ concentration measurements (year 2013) from the operational monitoring stations located in the BMR $(n=40)$ as dependent variable, and a set of spatial predictor parameters (i.e., independent variables) related to land cover type, geomorphology, climate, and population, that were considered to be the most relevant for distribution of $\mathrm{NO}_{2}$ concentrations.

\section{Erosion control}

A biophysical indicator could not be calculated for the supply of erosion control due to data availability limitations, so we applied an expert-based matrix model (Burkhard et al., 2012) using the regional land cover dataset as spatial data (Catalan Ministry of Territory and Sustainability, 2012). We applied a table of correspondences between the CORINE land cover types used in Burkhard et al. (2012) and the regional land cover types.

Following Burkhard et al. (2014) and Guerra et al. (2014), demand for erosion control was mapped using a soil loss potential index map developed by the Department of Geology of the Autonomous University of Barcelona for the Geographic Information System for the Network 
Important note: This is the author's post-print version of a research paper that was accepted for publication in the journal Ecosystem Services (Elsevier). Therefore, it underwent full peer review but has not been through the copyediting, typesetting, pagination and proofreading process, which may lead to differences between this version and the published version: Baró, F., Gómez-Baggethun, E., Haase, D., 2017. Ecosystem service bundles along the urban-rural gradient: Insights for landscape planning and management. Ecosyst. Serv. 24, 147-159. doi:10.1016/j.ecoser.2017.02.021

957

of Open Areas in the province of Barcelona $\left(\right.$ SITxell $\left.^{5}\right)$. The index is based on soil erodibility and topographic factors, but it does not include climate factors such as rainfall runoff. It defines four levels of soil loss potential, from 0 (negligible soil loss potential) to 3 (very high soil potential).

\section{Outdoor recreation}

Methods and data sources for mapping the supply (recreational potential index) and demand (recreational demand index) indicators of outdoor recreation in the BMR are fully described in Baró et al. (2016), hence here only a brief overview is provided. The model used here for assessing outdoor recreation focuses on nature-based recreational activities in the everyday life (Paracchini et al., 2014; Zulian et al., 2014). The rationale for assessing recreation capacity in this model can be summarized as follows: (1) the lesser human influence on landscapes, the higher value in terms of nature-based recreational potential; (2) protected natural areas and features (e.g., remarkable trees) are considered indicators of high recreational capacity; and (3) water bodies exert a specific attraction on the surrounding areas (Paracchini et al., 2014). Recreation capacity is hence mapped on the basis of the assessment of three components: degree of naturalness, nature protection, and presence of water. Each component was composed of one to four internal factors considered relevant in the case study of the BMR and for which spatial input data was available (see Baró et al., 2016). A score or weight (in the $0-1$ range) was assigned to every factor standing for their relative importance or impact in terms of recreation potential. The final selection of factors and definition of scores was based on a consultation process (via focus group) with four experts working in environmental planning and territorial analysis for the Barcelona Regional Council. The final dimensionless value of recreation capacity was normalized in the $0-1$ range.

Demand for outdoor recreation was mapped based on the availability of recreational sites (i.e., recreation capacity equal or higher than 0.4 ) close to people's homes and population density. A spatial cross-tabulation was carried out between a reclassified raster of Euclidian distances to recreation sites and the population density grid, assuming that all inhabitants in the case

\footnotetext{
${ }^{5}$ See http://www.sitxell.eu/en/mapa_geologia.asp
} 
Important note: This is the author's post-print version of a research paper that was accepted for publication in the journal Ecosystem Services (Elsevier). Therefore, it underwent full peer review but has not been through the copyediting, typesetting, pagination and proofreading process, which may lead to differences between this version and the published version: Baró, F., Gómez-Baggethun, E., Haase, D., 2017. Ecosystem service bundles along the urban-rural gradient: Insights for landscape planning and management. Ecosyst. Serv. 24, 147-159. doi:10.1016/j.ecoser.2017.02.021

study area have similar desires in terms of (everyday life) outdoor recreational opportunities, but their level of fulfillment depends on proximity to recreation sites (see cross-tabulation matrix in Baró et al., 2016). The resulting raster indicates ES demand in residential land following a 0 (i.e., no relevant demand) to 5 (i.e., very high demand) value range.

\section{References}

Baró, F., Palomo, I., Zulian, G., Vizcaino, P., Haase, D., Gómez-Baggethun, E., 2016. Mapping ecosystem service capacity, flow and demand for landscape and urban planning: A case study in the Barcelona metropolitan region. Land use policy 57, 405-417. doi:10.1016/j.landusepol.2016.06.006

Beelen, R., Hoek, G., Vienneau, D., Eeftens, M., Dimakopoulou, K., Pedeli, X., Tsai, M.-Y., Künzli, N., Schikowski, T., Marcon, A., Eriksen, K.T., Raaschou-Nielsen, O., Stephanou, E., Patelarou, E., Lanki, T., Yli-Tuomi, T., Declercq, C., Falq, G., Stempfelet, M., Birk, M., Cyrys, J., von Klot, S., Nádor, G., Varró, M.J., Dèdelè, A., Gražulevičiené, R., Mölter, A., Lindley, S., Madsen, C., Cesaroni, G., Ranzi, A., Badaloni, C., Hoffmann, B., Nonnemacher, M., Krämer, U., Kuhlbusch, T., Cirach, M., de Nazelle, A., Nieuwenhuijsen, M., Bellander, T., Korek, M., Olsson, D., Strömgren, M., Dons, E., Jerrett, M., Fischer, P., Wang, M., Brunekreef, B., de Hoogh, K., 2013. Development of NO2 and NOx land use regression models for estimating air pollution exposure in 36 study areas in Europe - The ESCAPE project. Atmos. Environ. 72, 10-23. doi:http://dx.doi.org/10.1016/j.atmosenv.2013.02.037

Burkhard, B., Kroll, F., Nedkov, S., Müller, F., 2012. Mapping ecosystem service supply, demand and budgets. Ecol. Indic. 21, 17-29. doi:http://dx.doi.org/10.1016/j.ecolind.2011.06.019

Burkhard, B., Kandziora, M., Hou, Y., Müller, F., 2014. Ecosystem Service Potentials, Flows and Demands Concepts for Spatial Localisation, Indication and Quantification. Landsc. Online 32, 1-32. doi:10.3097/LO.201434

Catalan Ministry of Agriculture, 2013. Areas, yields and productions of agricultural crops at the county level, year 2013. Retrieved from:

http://agricultura.gencat.cat/web/sites/agricultura/.content/de_departament/de02_estadistiques_observatoris/0 2_estructura_i_produccio/02_estadistiques_agricoles/01_llencols_definitius/fitxers_estatics/produccions_co marcals/Produccions_comarcals_web_2013.xls

Catalan Ministry of Territory and Sustainability, 2012. Cartography of habitats in Catalonia 1:50,000, version 2 (2008-2012). Retrieved from:

http://territori.gencat.cat/ca/01_departament/12_cartografia_i_toponimia/bases_cartografiques/medi_ambient _i_sostenibilitat/cartografia_en_format_miramon_sig/bases_disponibles/territori/29_habitats_1_5000_perfull

Gracia, C., Ibàñez, J.J., Burriel, J.A., Mata, T., Vayreda, J., 2000-2004. Inventari Ecològic i Forestal de Catalunya. CREAF, Bellaterra. ISBN: 84-931323-0-6.

Guerra, C., Pinto-Correia, T., Metzger, M., 2014. Mapping Soil Erosion Prevention Using an Ecosystem Service Modeling Framework for Integrated Land Management and Policy. Ecosystems 17, 878-889. doi:10.1007/s10021-014-9766-4

INE (Instituto Nacional de Estadística, Spanish Statistical Office), 2009. Spanish Agricultural Census. Retrieved from: http://www.ine.es/censoagrario/censoag.htm

INE (Instituto Nacional de Estadística, Spanish Statistical Office), 2011. Census tract database. Retrieved from: http://www.ine.es/censos2011_datos/cen11_datos_resultados_seccen.htm

LCMC (Land Cover Map of Catalonia), 2009. Land Cover Map of Catalonia. $4^{\text {th }}$ edition. CREAF and Generalitat de Catalunya. Retrieved from: http://www.creaf.uab.es/mcsc/usa/index.htm

Paracchini, M.L., Zulian, G., Kopperoinen, L., Maes, J., Schägner, J.P., Termansen, M., Zandersen, M., PerezSoba, M., Scholefield, P.A., Bidoglio, G., 2014. Mapping cultural ecosystem services: A framework to assess the potential for outdoor recreation across the EU. Ecol. Indic. 45, 371-385. doi:10.1016/j.ecolind.2014.04.018 
Important note: This is the author's post-print version of a research paper that was accepted for publication in the journal Ecosystem Services (Elsevier). Therefore, it underwent full peer review but has not been through the copyediting, typesetting, pagination and proofreading process, which may lead to differences between this version and the published version: Baró, F., Gómez-Baggethun, E., Haase, D., 2017. Ecosystem service bundles along the urban-rural gradient: Insights for landscape planning and management. Ecosyst. Serv. 24, 147-159. doi:10.1016/j.ecoser.2017.02.021

Pino, J., 2007. Primera proposta de bases cartogràfiques, criteris i mètodes per a l'avaluació de l'estat ecològic del bosc a l'àmbit SITxell $i$ de les seves tendències a curt termini. Unpublished report for the Barcelona Regional Council.

Pistocchi, A., Zulian, G., Vizcaino, P., Marinov, D., 2010. Multimedia Assessment of Pollutant Pathways in the Environment, European Scale Model (MAPPE-EUROPE). EUR 24256 EN. Luxembourg (Luxembourg): Publications Office of the European Union; 2010. JRC56335.

Unió de Pagesos, 2013. Actualització de l'avaluació i perspectives territorials dels usos agraris en l'àmbit del Sitxell. Unpublished report for the Barcelona Regional Council.

van Oudenhoven, A.P.E.E., Petz, K., Alkemade, R., Hein, L., de Groot, R.S., 2012. Framework for systematic indicator selection to assess effects of land management on ecosystem services. Ecol. Indic. 21, 110-122. doi:http://dx.doi.org/10.1016/j.ecolind.2012.01.012

Zulian, G., Polce, C., Maes, J., 2014. ESTIMAP: a GIS-based model to map ecosystem services in the European union. Ann. di Bot. 4, 1-7. doi:10.4462/annbotrm-11807 